\title{
The Multifaceted COVID-19: CT Aspects of Its Atypical Pulmonary and Abdominal Manifestations and Complications in Adults and Children. A Pictorial Review
}

\author{
Chiara Morelli ${ }^{1, *}$, Mariantonietta Francavilla ${ }^{2}$,, Amato Antonio Stabile Ianora ${ }^{1}$, Monica Cozzolino ${ }^{1}$ (D), \\ Alessandra Gualano ${ }^{1}$, Giandomenico Stellacci ${ }^{2}$, Antonello Sacco ${ }^{1}$, Filomenamila Lorusso ${ }^{1}$, Pasquale Pedote ${ }^{1} \mathbb{D}$, \\ Michele De Ceglie ${ }^{1}$ and Arnaldo Scardapane ${ }^{1}$ iD
}

1 Interdisciplinary Department of Medicine, Section of Diagnostic Imaging, University of Bari Medical School, 70124 Bari, Italy; amatoantonio.stabileianora@uniba.it (A.A.S.I.); monicacoz@hotmail.it (M.C.); alegualano@gmail.com (A.G.); sacccoanto@gmail.com (A.S.); milalorusso@yahoo.it (F.L.); pedoterx@gmail.com (P.P.); micheledeceglie@libero.it (M.D.C.); arnaldo.scardapane@gmail.com (A.S.)

2 Unit of Pediatric Imaging, Giovanni XXIII Hospital, 70126 Bari, Italy; marianto_fra@hotmail.it (M.F.); gstellacci@icloud.com (G.S.)

* Correspondence: dottchiaramorelli@gmail.com

check for updates

Citation: Morelli, C.; Francavilla, M.; Stabile Ianora, A.A.; Cozzolino, M.; Gualano, A.; Stellacci, G.; Sacco, A.; Lorusso, F; Pedote, P.; De Ceglie, M.; et al. The Multifaceted COVID-19: CT Aspects of Its Atypical Pulmonary and Abdominal Manifestations and Complications in Adults and Children. A Pictorial Review. Microorganisms 2021, 9, 2037. https:// doi.org/10.3390/microorganisms9102037

Academic Editor:

Sofia Costa-de-Oliveira

Received: 31 July 2021

Accepted: 23 September 2021

Published: 26 September 2021

Publisher's Note: MDPI stays neutral with regard to jurisdictional claims in published maps and institutional affiliations.

Copyright: () 2021 by the authors. Licensee MDPI, Basel, Switzerland. This article is an open access article distributed under the terms and conditions of the Creative Commons Attribution (CC BY) license (https:// creativecommons.org/licenses/by/ $4.0 /)$.

\begin{abstract}
Our daily experience in a COVID hospital has allowed us to learn about this disease in many of its changing and unusual aspects. Some of these uncommon manifestations, however, appeared more frequently than others, giving shape to a multifaceted COVID-19 disease. This pictorial review has the aim to describe the radiological aspects of atypical presentations and of some complications of COVID-19 disease in adults and children and provide a simple guide for radiologists to become familiar with the multiform aspects of this disease.
\end{abstract}

Keywords: COVID-19; atypical manifestation; CT; adult; children; pulmonary; abdominal

\section{Introduction}

On 31 December 2019, the Chinese health authority announced an outbreak of pneumonia cases of unknown etiology in Wuhan (Hubei, China). On 9 January 2020, the China Center for Disease Control and Prevention (CDC, Beijiing CHN) identified a new coronavirus (temporarily named 2019-nCoV) as the etiological cause of this disease. They later confirmed the inter-human transmission of the virus. On 11 February, the World Health Organization (WHO, Geneva CH) announced that pneumonia caused by 2019-nCoV was called COVID-19 (Corona Virus Disease 19). The Coronavirus Study Group of the International Committee on Taxonomy of Viruses has classified the virus under the name of SARS-CoV-2, associating it with the coronaviruses that cause severe acute respiratory syndrome (SARS-CoVs, severe acute respiratory syndrome coronaviruses). On 11 March 2020, the WHO, after assessing the severity levels and global spread of the SARS-CoV-2 infection, declared the COVID-19 pandemic. There are 190,770,507 confirmed cases in the world since the beginning of the pandemic and 4,095,924 deaths [1].

While Reverse Transcriptase Polymerase Chain Reaction (RT PCR) remains the diagnostic gold standard of infection, computed tomography (CT) has been shown to have a fundamental role in diagnosis, especially in those patients with false negative RT PCR results, with a sensitivity of approximately $98 \%$. The CT examination allows us to monitor the progression of the disease and evaluate the multi-organ involvement. Thanks to $\mathrm{CT}$, we have learned to recognize the typical pulmonary presentation (which we will describe below). Nevertheless, both the literature data and our direct experience require us to keep in mind that this pathology can often show itself "in disguise", giving atypical, non-classical, unexpected and complicated manifestations: it is necessary to know them in order to avoid misunderstandings. 
Typical SARS-CoV-2 pneumonia is well known and it is characterized by bilateral, multilobar, peripheral, subpleural ground glass opacity [2] (Figure 1). In the most advanced stages of the disease, however, parenchymal consolidations, and thickening of the interlobular septa with crazy paving patterns will be frequently visible [3].

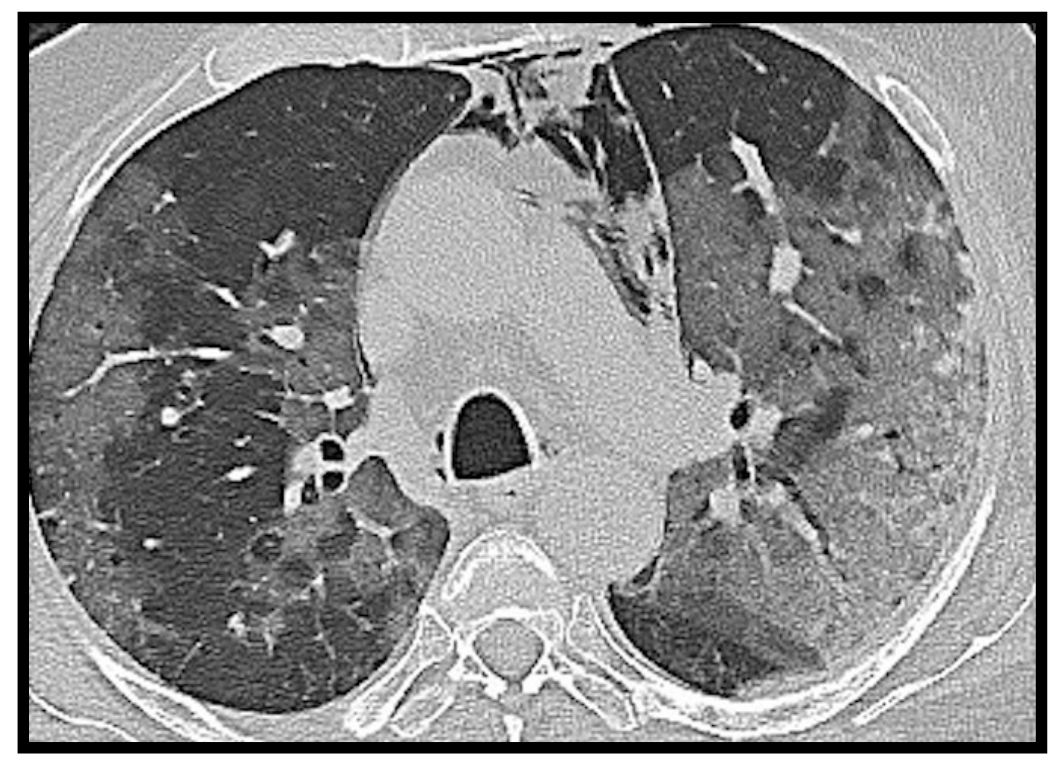

Figure 1. Computed tomography (CT) axial image of ground glass opacity. A hospitalized COVID19 patient with fever and dyspnea. The axial CT image shows bilateral ground glass opacities with peripheral subpleural disposition in the right lung and tending to confluence in the left lung. Spontaneous pneumomediastinum is associated.

Atypical manifestations may affect both adult and pediatric patients with pulmonary and extra-pulmonary involvement.

\section{Adult "Atypical" and "Complicated" Pulmonary COVID-19}

Lymphadenopathy, pleural effusion, pericardial effusion, bronchiectasis, halo sign and reverse halo sign, cavitation and some complications, such as spontaneous pneumothorax and pneumomediastinum, are reported as either pulmonary unusual manifestations or atypical complications of COVID-19 [4-7]. As we will clarify below, if lymphadenopathies are more often found in acute phase of the disease, the pleural effusion is frequently identified in the advanced stages. Furthermore, while lymphadenopathies are linked to patients with stronger immune response, pericardial effusion is associated with the worst COVID-19 cases, in which heart damage coexists.

\subsection{Lymphadenopathy}

With the term "lymphadenopathy" we refer to mediastinal lymph nodes $>10 \mathrm{~mm}$ and hilar lymph nodes $>3 \mathrm{~mm}$ in short axis diameter. As already reported by Li et al. [8], and by Grassi et al. [9], lymphadenopathies are part of the acute COVID-19 manifestations even if they do not represent a specific and characteristic sign (Figure 2). Xiao Li et al. [10] reported that hilar and mediastinal lymph node enlargement was observed in $43.51 \%$ of patients with COVID-19 pneumonia. Their study suggested that enlarged hilar and mediastinal lymph nodes are associated with immune response and that patients with COVID-19 pneumonia have stronger immune response especially in moderate and severe conditions. 

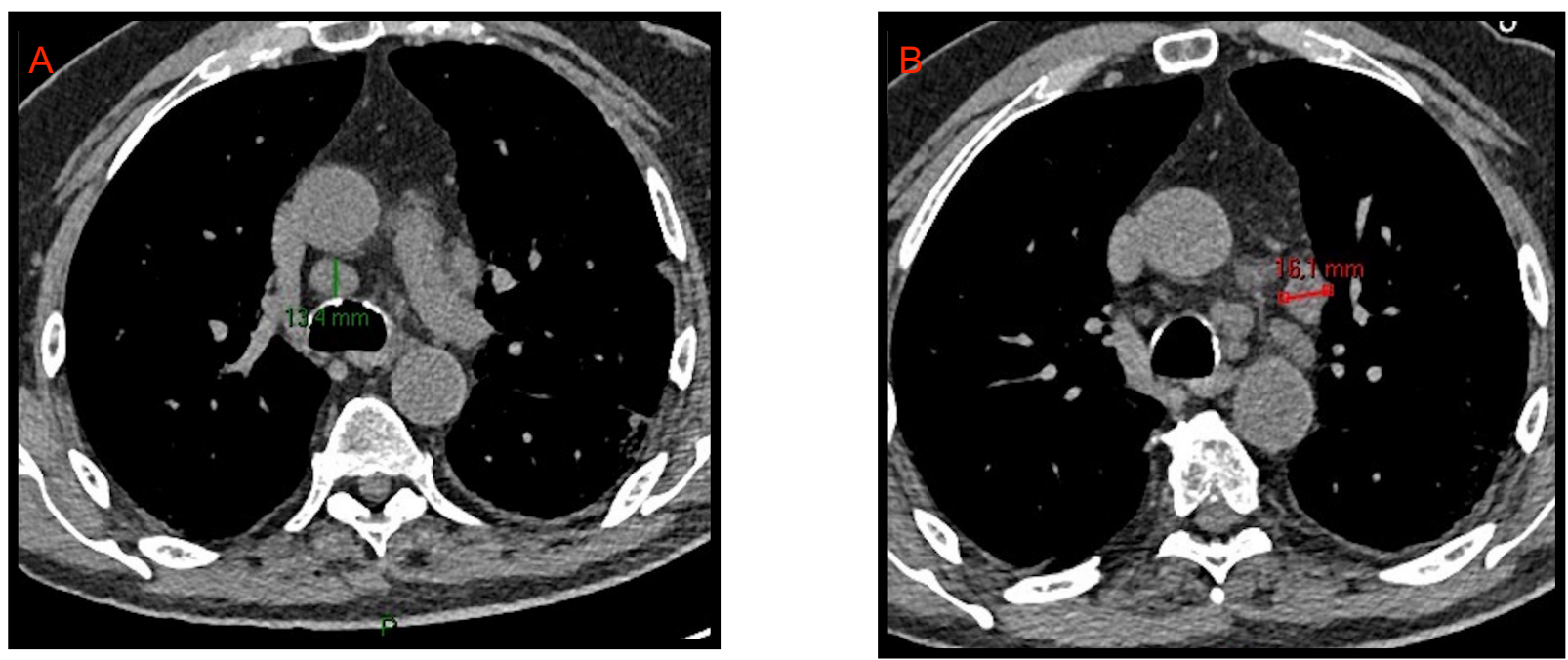

Figure 2. CT axial images of mediastinal lymphadenopathies. Enlarged lymph nodes with short axis of $13.4 \mathrm{~mm}$ and $16.1 \mathrm{~mm}$ are evident in the lower pre-tracheal space (A) and in the aorto-pulmonary window (B), respectively.

\subsection{Pleural Effusion}

Pleural effusion is rarely associated with COVID-19. We often find it in the most critically ill patients and in the most advanced stages of the disease (Figure 3). Zhou [11] et al. described pleural effusion in 3.2\% of COVID-19 patients while Grassi et al. [9] observed it in $14.3 \%$ of cases. Darwish et al. [12] found that during the first week of infection pleural effusion occurs only in $13.6 \%$ of patients. Xiao li et al. [10], in regard to pleural effusion, reported a frequency of $14.3 \%$ and concluded that it was not significantly associated with COVID-19 pneumonia.
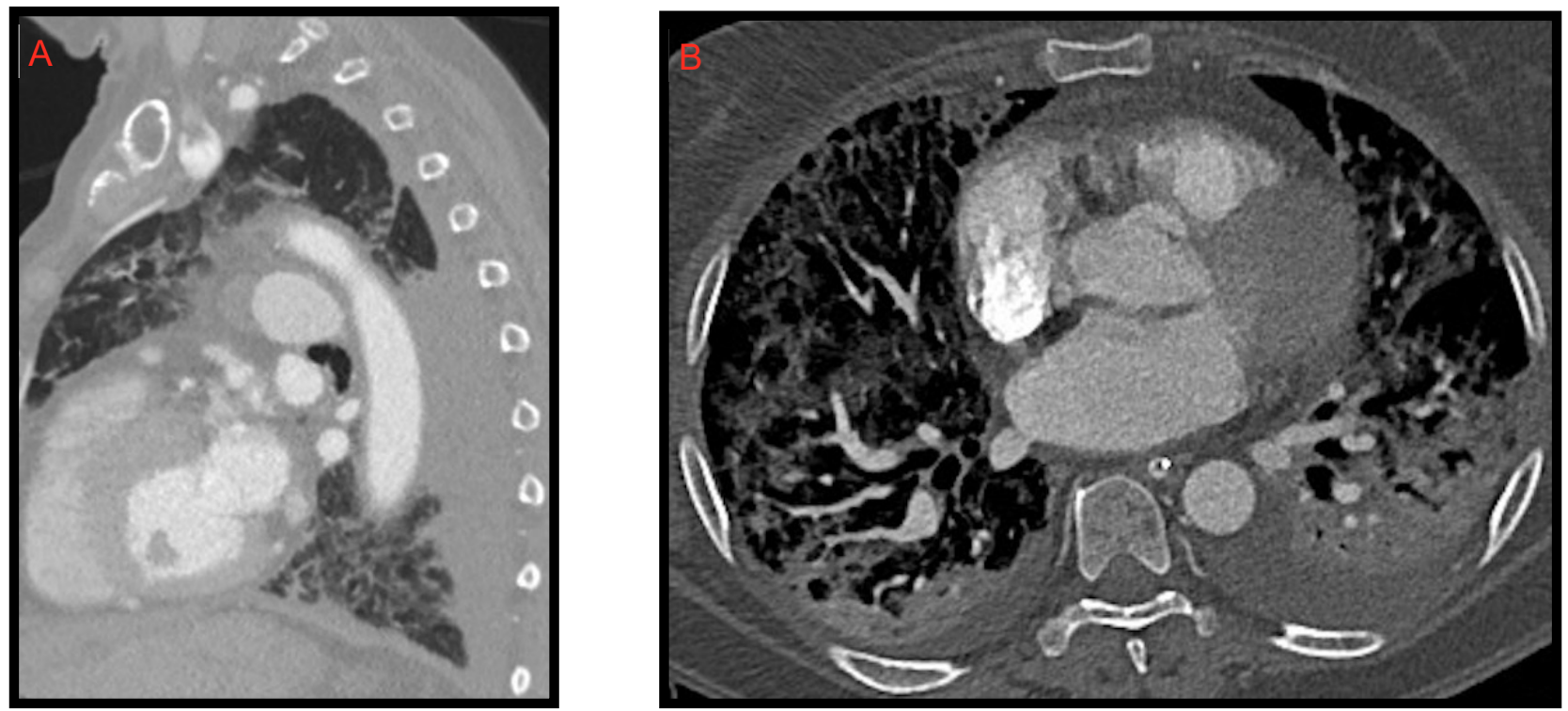

Figure 3. A 58-year-old female patient with worsening respiratory function on the 10th day of hospitalization evaluated with CT. Sagittal (A) and axial (B) images show posterior pleural effusion greater on the left side.

\subsection{Pericardial Effusion}

Pericardial effusion can be defined as the presence of more than $50 \mathrm{~mL}$ of liquid between the pericardial sheets. As already mentioned for the pleural effusion it is not characteristic of the COVID-19 thoracic involvement. In fact, it was observed by Li et al. [8] 
in $4.8 \%$ of cases. However, in this study, it is also described as a manifestation associated with the most compromised patients (Figure 4).
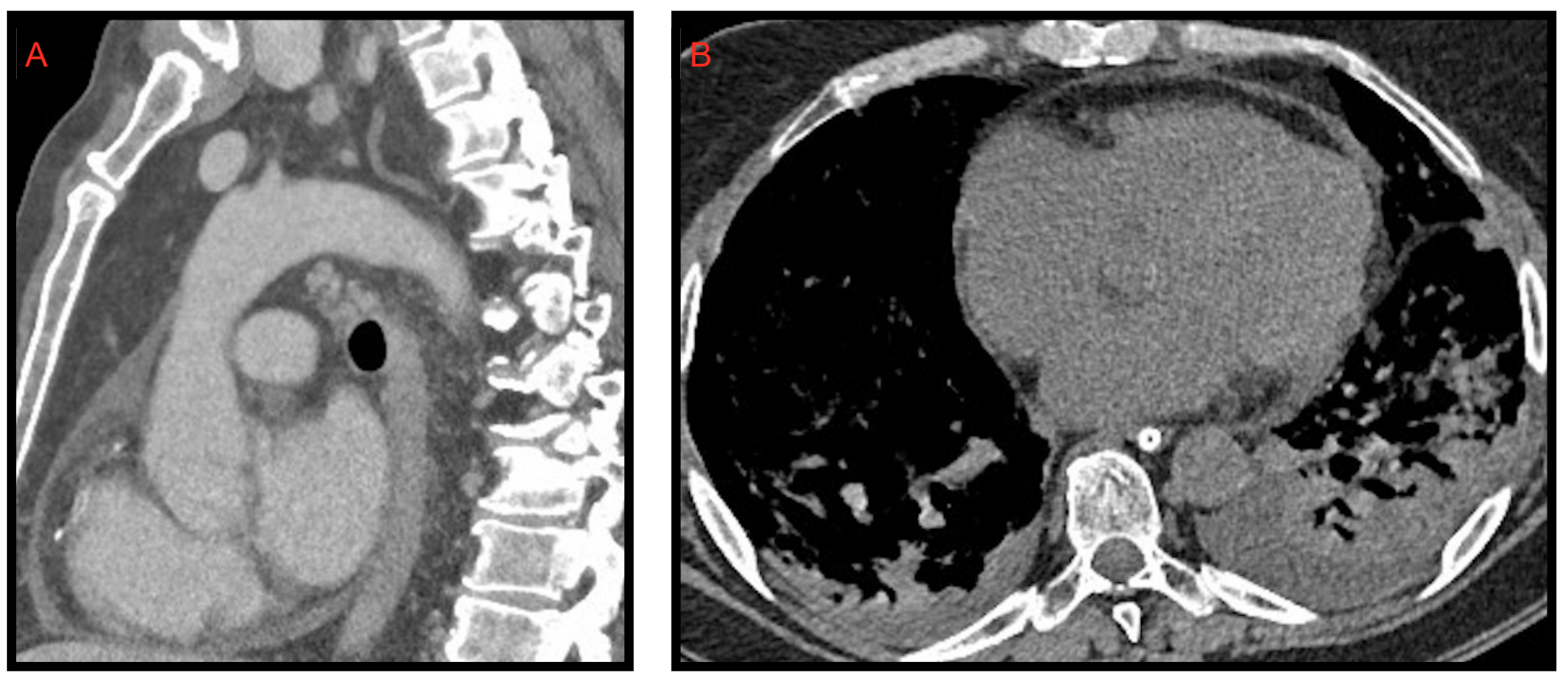

Figure 4. Pericardial effusion on CT, sagittal (A) and axial (B) images, in two patients admitted to intensive care unit. In image B, bilateral pleural effusion is also noted.

Ali Sabri et al. [13] found a 7.9\% frequency of pericardial effusion. Furthermore, from their analysis, it emerged that pericardial effusion could be considered an important factor for admission to intensive care unit (ICU), as it could be an indicator of myocarditis or cardiomyopathy caused by COVID-19, but they did not confirm this hypothesis with echocardiography.

Grassi et al. [9] describe pericardial effusion in $16.7 \%$ of patients, proposing a relation with heart damage; Shi et al. [14] associated it with a higher risk of in-hospital mortality.

\subsection{Bronchiectasis}

Although bronchiectasis is not a typical COVID-19 manifestation (as noticed by Salehi et al. [15]), it has been reported with a very high frequency (41.3\%) by Auger et al. [16] They hypothesize that their result is probably due to the particularly compromised clinical status of the patients included in the study. Devie et al. [17] detected bronchiectases and traction bronchiectases in $25.3 \%$ of cases, and concluded that these cases were significantly more frequent in the most severe group of patients.

\subsection{Halo Sign and Reverse Halo Sign}

Halo sign consists of a shaded area of increased parenchymal density surrounded by peripheral ground glass changes. It was studied by $\mathrm{Wu}$ and Chen et al. [18], who discovered it in 18/130 COVID-19 patients (13\%), considering it as an unusual feature associated with the initial phase of the disease. The reverse halo sign can be defined as a clearly rounded area of "ground glass-like" increased parenchymal density, circumscribed by a consolidation ring (Figure 5). It likely represents the disease progression towards consolidation as described by Bernheim et al. [19], who detected it in $4 \%$ of the patients studied at 6-12 days of infection. 


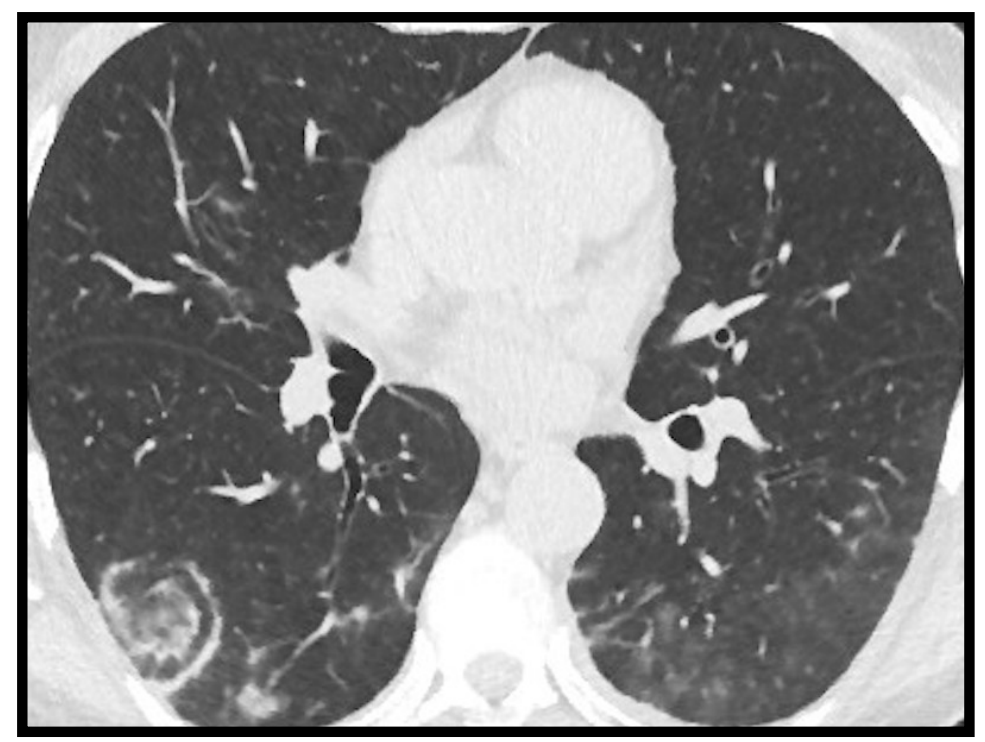

Figure 5. Reverse halo sign in right lower lobe in COVID-19.

Kuang et al. [20] conducted a study aimed to identify the CT differences between H1N1 influenza pneumonia and COVID-19. Their results showed that the reverse halo sign in COVID-19 pneumonia was present in $18.5 \%$ of cases, and that this sign was more common than in H1N1 influenza pneumonia $(p<0.05)$.

\subsection{Cavitation}

Cavitation is quite rare in viral pneumonia and consequently also in SARS-CoV-2 and MERS-CoV pneumonias [21-23].

Zoumut et al. [24] investigated the development of lung cavitation in patients with severe COVID-19 disease treated in ICU; a frequency of $11 \%$ was detected. They assumed that cavitation was due to several factors such as bacterial and fungal coinfection, immunosuppressive effects of glucocorticoids and tocilizumab, inflammatory state induced by SARS-CoV-2, and thrombotic diathesis (Figure 6). This study also reported that lung cavitation in patients with severe COVID-19 lung disease can occur and is associated with secondary complications, such as hemoptysis and pneumothorax, conferring a poor prognosis.

\subsection{Pneumothorax and Pneumomediastinum}

As delineated by Vega et al. [25], a cough, typically present in COVID-19 disease, is the cause of these two complications (Figures 7 and 8). They illustrate three cases of spontaneous pneumothorax and pneumomediastinum and argue that, although the development of pneumothorax is usually secondary to barotrauma in patients in ICU, their patients did not require, at diagnosis, assisted mechanical ventilation. They concluded that in their cases the severity of the disease was associated with these rare complications.

Loffi et al. [26] identified 6 cases of spontaneous pneumomediastinum in 102 COVID-19 patients investigated with CT examination (6\%). They asserted that spontaneous pneumomediastinum is a possible complication of severe COVID-19 pneumonia and can affect patient management and clinical outcomes. In fact, in their experience "the concomitant presentation of spontaneous pneumomediastinum and diffuse COVID-19 pneumonia was associated with a severe clinical course characterized by sudden ARDS that required aggressive management and early intubation in three patients".

Table 1 summarizes all the studies reported in Section 2: Adult "Atypical" and "Complicated" Pulmonary COVID-19. 


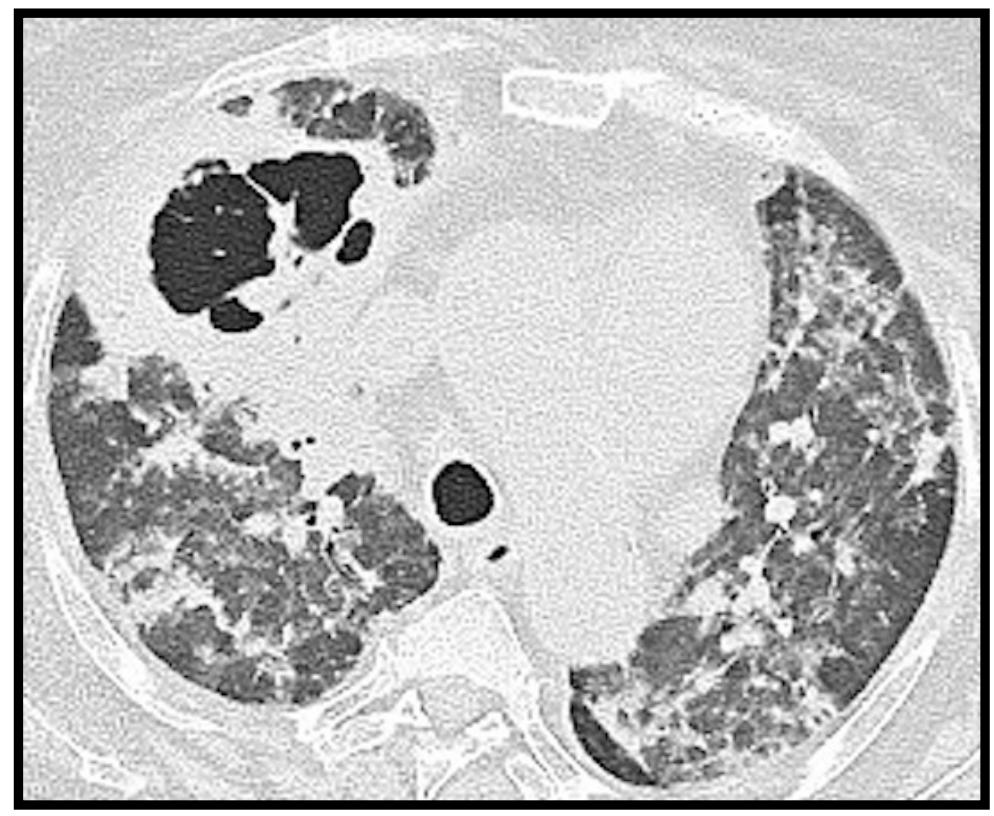

Figure 6. Axial CT image of a 70-year-old female patient. Gross parenchymal consolidation with central excavation suspected for superinfection is evident in the anterior segment of the right upper lobe. In addition, reinforcing suspicion of superinfection, the study was negative for pulmonary embolism.
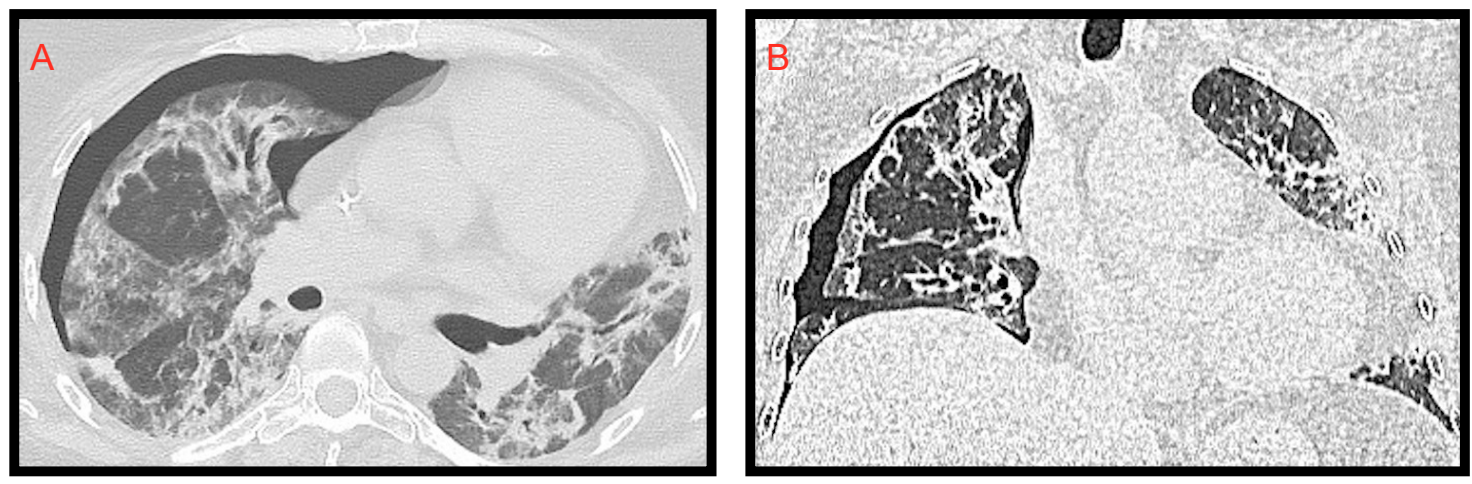

Figure 7. Spontaneous right pneumothorax extended from apex to lung base. Axial (A); coronal (B); the right lung appears hypo-expanded.

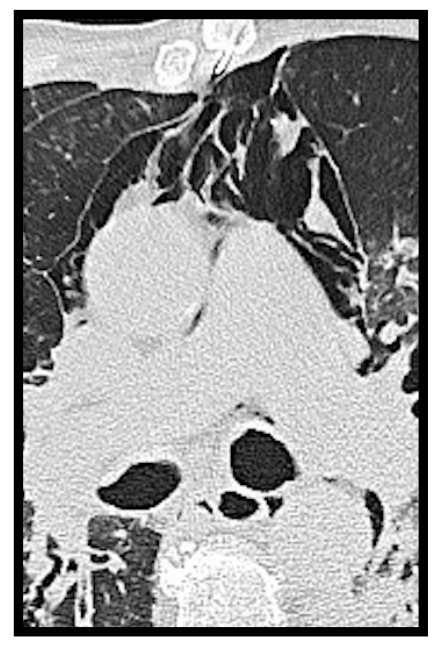

Figure 8. Spontaneous pneumomediastinum in a COVID-19 patient. 
Table 1. Adults "atypical" and "complicated" pulmonary COVID-19.

\begin{tabular}{|c|c|c|c|c|c|c|c|c|}
\hline & Lymphadenopathy & $\begin{array}{l}\text { Pleural } \\
\text { Effusion }\end{array}$ & $\begin{array}{l}\text { Pericardial } \\
\text { Effusion }\end{array}$ & Bronchiectasis & $\begin{array}{l}\text { Halo Sign/ } \\
\text { Reverse } \\
\text { Halo Sign }\end{array}$ & Cavitation & $\begin{array}{l}\text { PNX }^{* 1} \\
\text { PNM }^{*}\end{array}$ & \\
\hline Authors & & & & & & & & Total \\
\hline Li et al. [8] & $8.4 \%$ & & $4.8 \%$ & & & & & 83 \\
\hline Grassi et al. [9] & $54.8 \%$ & $14.3 \%$ & $16.7 \%$ & & & & & 126 \\
\hline Xiao li et al. [10] & $43.5 \%$ & $14.3 \%$ & & & & & & 154 \\
\hline Zhou et al. [11] & & $3.2 \%$ & & & & & & 62 \\
\hline Darwish et al. [12] & & $13 \%$ & & & & & & 95 \\
\hline Ali Sabri et al. [13] & & & $7.9 \%$ & & & & & 63 \\
\hline Romain A. et al. [16] & & & & $41.3 \%$ & & & & 109 \\
\hline Devie A. et al. [17] & & & & $25.3 \%$ & & & & 158 \\
\hline Wu and Chen et al. [18] & & & & & $13.8 \% /-$ & & & 130 \\
\hline Bernheim et al. [19] & & & & & $-/ 4 \%$ & & & 121 \\
\hline Kuang et al. [20] & & & & & $-/ 18.5 \%$ & & & 405 \\
\hline Zoumut et al. [24] & & & & & & $11 \%$ & & 110 \\
\hline Vega et al. [25] (case rep.) & & & & & & & $\begin{array}{l}3 \text { case of } \\
\text { PNX and } \\
\text { PNM }\end{array}$ & - \\
\hline Loffi et al. [26] & & & & & & & $-/ 6 \%$ & 102 \\
\hline
\end{tabular}

*PNX: pneumothorax; *PNM: pneumomediastinum.

\section{Children's "Atypical" and "Complicated" Thoracic COVID-19 Manifestations}

As in the adult case series, in pediatric patients COVID-19 pneumonia manifested more frequently with some "typical" features, such as ground glass opacity (GGO), peribronchial thickening, vascular engorgement and airspace consolidation [27-30]; as stated also by the international consensus [31] regarding pediatric chest imaging. Atypical imaging findings are represented by pleural effusion, atelectasis, nodules, linear opacities, lymphadenopathy, pneumothorax and pneumomediastinum.

\subsection{Pleural Effusion}

Caro-Dominguez et al. [27] found pleural effusion in 7\% of their cases, Ugas-Charcape et al. [30] described it in $6 \%$ and $13 \%$ of chest radiographs and CTs, respectively, while Zhang et al. [29] reported no cases of pleural effusion.

Pleural effusion (Figure 9) was found to be more significantly present in the frame of MIS-C, a pathological multifactorial entity described below.

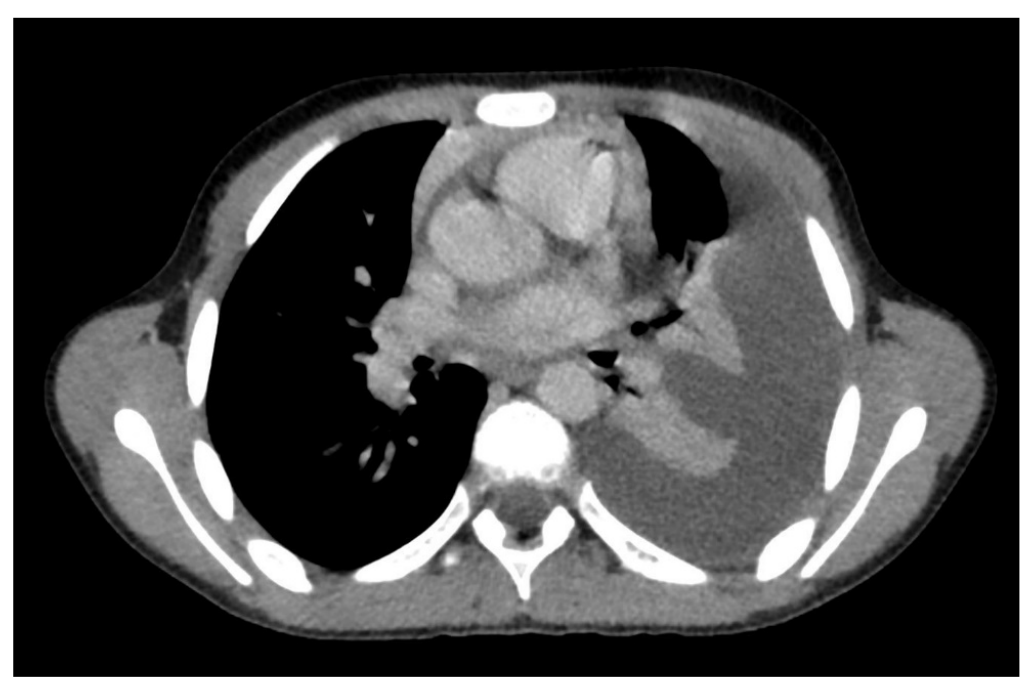

Figure 9. Pleural effusion of the left lung with associated pulmonary atelectasis in a 10-year-old boy. 


\subsection{Atelectasis}

The case series reports atelectasis in a few cases: $2 \%$ according to Caro-Dominguez et al. [27] and Ugas-Charcape et al. [30]. This feature has been related to the presence of associated pneumothorax and pleural effusion (Figure 9), or to an incorrect position of the endotracheal tube [27].

\subsection{Nodules and Linear Opacities}

In a number of studies "nodules" refer to well-defined ground glass opacities.

Caro-Dominguez et al. [27] described pulmonary nodules in 25\% of cases and linear opacities in 33\% of chest CT examinations. In a case series from Latin America [30] these findings were reported in $9.7 \%$ and $15.6 \%$ of pediatric patients, respectively.

\subsection{Lymphadenopathy}

Lymphadenopathy, both hilar and mediastinal, as in the adult series, is an infrequent feature in chest $\mathrm{CT}$ examinations. It was categorized as an atypical finding in the international consensus statement of chest imaging in pediatric COVID-19 patients [31]. In a subgroup of studies, it has low prevalence: $17 \%$ according to Caro-Dominguez et al. [27] and $18 \%$ according to Zhang et al. [29]; other studies did not find any cases of thoracic lymphadenopathy $[22,30,32]$ in children affected by COVID-19.

\subsection{Pneumothorax and Pneumomediastinum}

Spontaneous pneumothorax and pneumomediastinum (Figure 10) are also very infrequent findings in pediatric COVID-19-related pneumonia: a study [27] reported pneumothorax in $2 \%$ of cases, and a few case reports in the literature have described these findings $[33,34]$, usually in adolescents with severe disease.

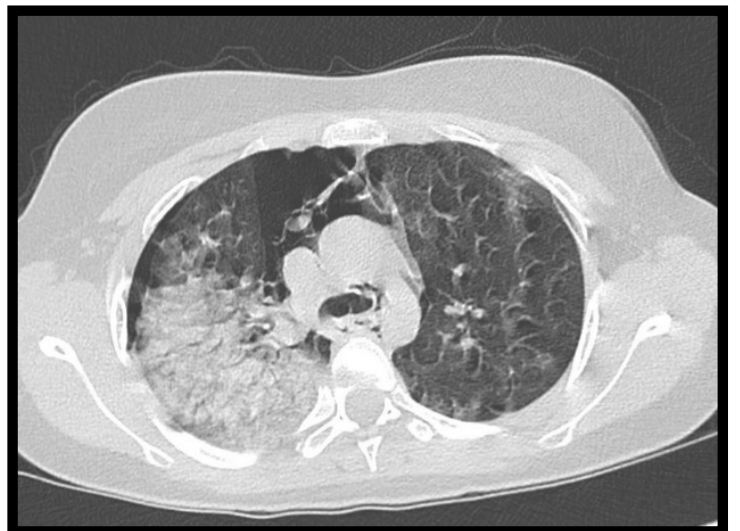

(A)

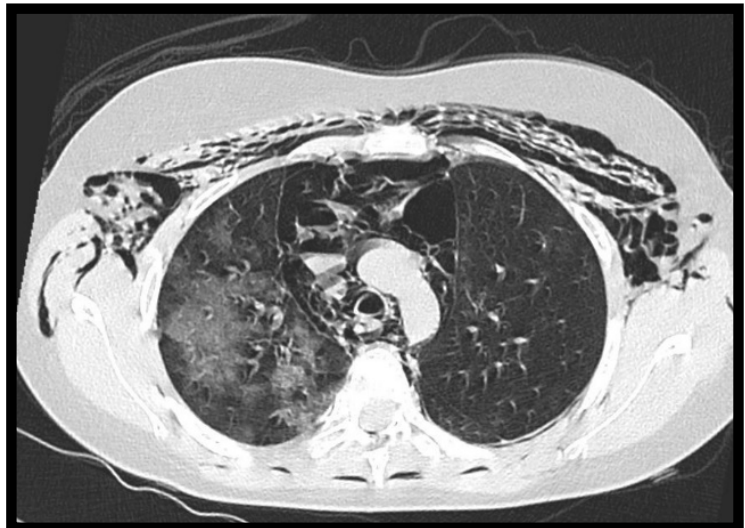

(B)

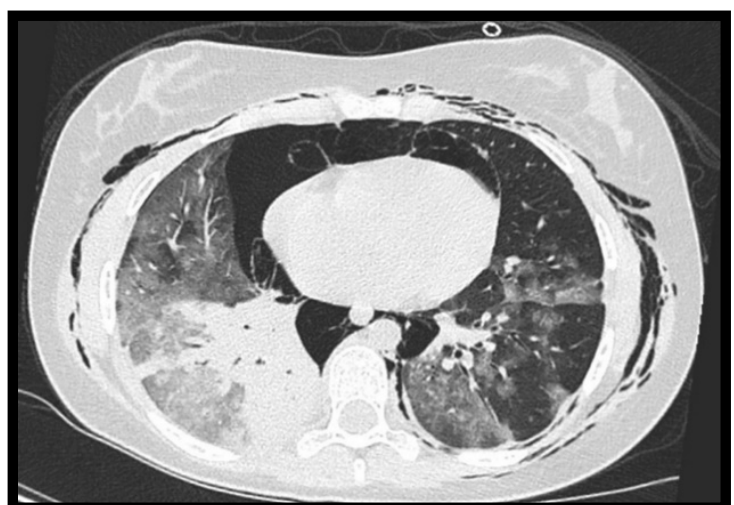

(C)

Figure 10. (A-C): A 14-year-old girl with spontaneous pneumothorax and pneumomediastinum, in association with extensive ground glass changes. In Figure 10C consolidation of the right lower lobe is noted. 
Table 2 summarizes all the studies reported in Section 3: Children's "Atypical" And "Complicated" Thoracic COVID-19 Manifestations.

Table 2. Children's "Atypical" and "Complicated" Thoracic COVID-19 Manifestations.

\begin{tabular}{cccccc}
\hline & Lymphadenophaty & $\begin{array}{c}\text { Pleural } \\
\text { Effusion }\end{array}$ & Atelectasis & $\begin{array}{c}\text { Nodules/ } \\
\text { Linear } \\
\text { Opacities }\end{array}$ & $\begin{array}{c}\text { PNX/ } \\
\text { PNM }\end{array}$ \\
\hline Authors & $17 \%$ & & & & Total \\
\hline Dominguez et al. [27] & $18 \%$ & $7 \%$ & $2 \%$ & $25 \% / 33 \%$ & $2 \% /-$ \\
\hline Zhang et al. [29] & $0 \%$ & $0 \%$ & & & 41 \\
\hline Charcape et al. [30] & $13 \%$ & $2 \%$ & $9.7 \% / 15.6 \%$ & 140 \\
\hline
\end{tabular}

\subsection{Cardiothoracic Mis-C}

A hyperinflammatory immune-mediated shock syndrome has been recognized in children aged $<19$ years were exposed to the severe acute respiratory syndrome coronavirus 2 (SARS-CoV-2). The WHO [35] and United States Center for Disease Control and Prevention (CDC) [36] refer to this entity as Multisystem Inflammatory Syndrome in Children (MIS-C).

The diagnostic criteria of MIS-C have been defined by the WHO [35] and includes biochemical evidence of elevated inflammatory markers, absence of other microbial causes and evidence of organ dysfunction (e.g., hypotension, shock, myocardial dysfunction). At the time of this report more than 4000 cases have been collected worldwide [36].

Affected patients present a wide spectrum of clinical findings consisting of fever, headache, pain at the extremities, abdominal pain, vomiting and diarrhea, skin rash, conjunctivitis and peripheral oedema, with variable severity, with a significant percentage evolving to myocardial damage and cardiogenic, septic or toxic shock [37]. Laboratory data measured in affected children show a marked pro-inflammatory state [38].

The post-viral hyperinflammatory process presumed to cause MIS-C results in unique thoracic imaging abnormalities that differ from the classic manifestations of acute pediatric COVID-19 infection [39].

Although radiological findings are not typical, they may be red flags for the diagnosis of MIS-C when matched with clinical and laboratory data [40].

According to a number of studies the most common X-ray and CT findings are as follows: perihilar opacity and peribronchial thickening; pleural effusion and cardiomegaly [39,40]; atelectasis, airspace consolidation and diffuse ground glass appearance [41-44].

Cardiac CT and MRI can also show heart failure with left ventricular systolic dysfunction, myocardial oedema, pericardial effusion and coronary artery dilatation [40-43], the latter in the frame of the so-called Kawasaki-like disease [45], the well-known vasculitis that affects the medium calibre vessels in children.

\section{Adult "Abdominal" COVID-19}

In recent times, the efforts of the international scientific community aimed to define the abdominal manifestations of COVID-19, even if there is a small number of studies published on this topic. Although the pathogenetic mechanisms have yet to be clarified, we know that SARS-CoV-2 enters cells by exploiting the ACE-2 receptor which is widely expressed in the GI tract, pancreas, biliary tract and vascular endothelium [46-48]. It is also known that critical patients with COVID-19 have systemic coagulopathy and a thrombotic diathesis supported by the important underlying inflammatory process [48-51]. Although pulmonary embolism is the most frequent thrombotic complication in these patients, arterial thrombosis could be equally relevant and its presentation as acute aortic occlusion would be evocative [52]. Baeza et al. [53] presented three cases of acute aortic occlusion (AAO) and concluded that despite the pre-existence of risk factors in these patients, there is likely an association between COVID-19 infection and the development of a prothrombotic state leading to significant arterial complications (Figure 11). 

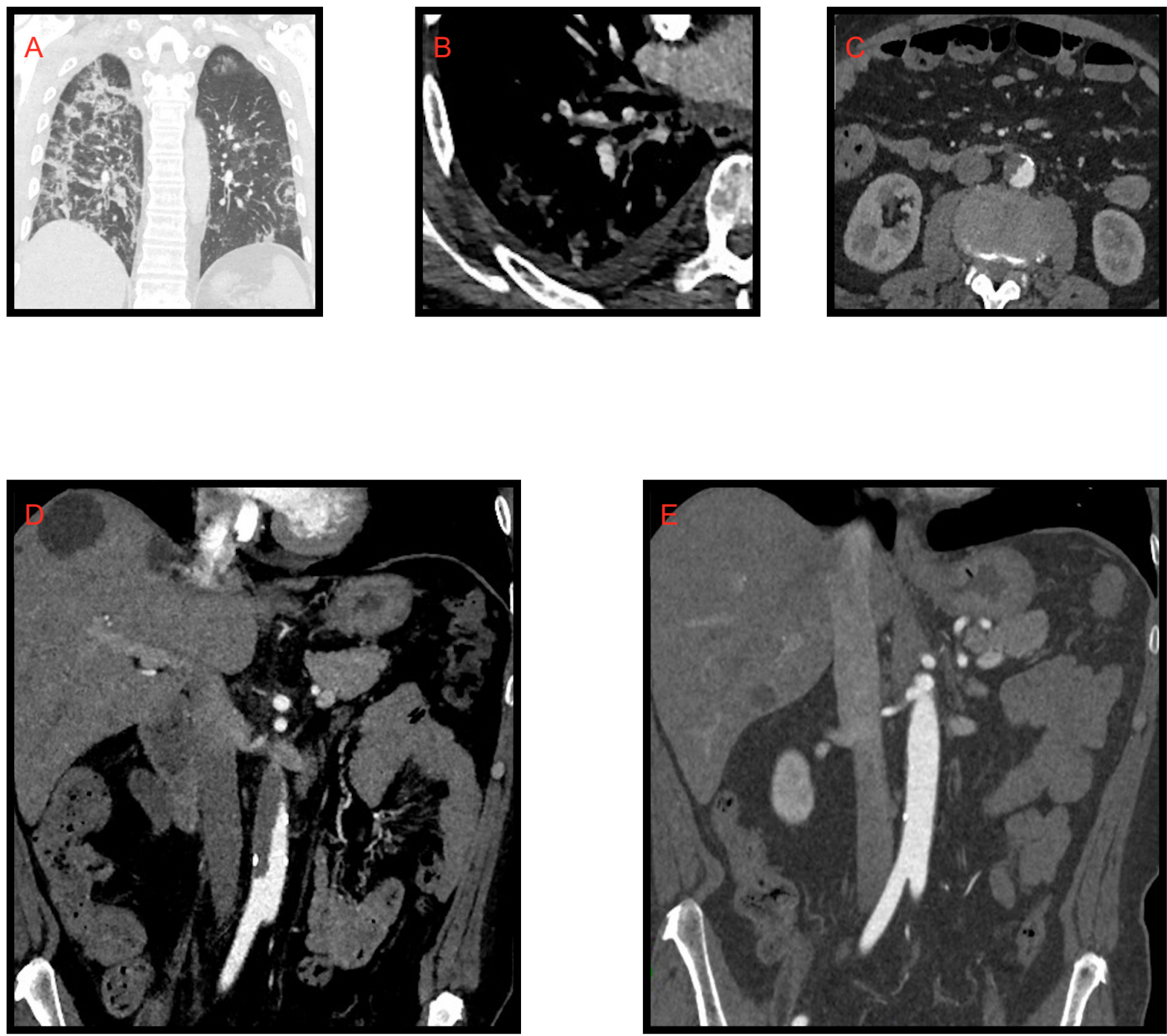

Figure 11. Case of acute aortic parietal thrombosis in patient affected by SARS-CoV-2 pneumonia. Image (A) shows the lung's involvement caused by COVID-19 pneumonia. Thromboembolic opacification defect of a segmental (anterior) arterial branch for the right lower lobe is associated (B). (C) Axial images of subrenal acute aortic thrombosis. In coronal image (D) is it possible to notice the acute aortic thrombosis which extends craniocaudally for about $6 \mathrm{~cm}$. (E) Complete resolution of aortic thrombosis after therapy.

This helps to clarify the pathogenetic mechanisms underlying pancreatitis, colitis and abdominal infarction in COVID-19, although further studies are needed.

\subsection{Kidney, Splenic and Intestinal Infarction}

Goldberg-Stein et al. [46] found splenic and renal infarction in 5\% of COVID-19 patients investigated with CT examination, related to a state of hypercoagulation.

As described by Bhayana et al. [48] and Goldberg-Stein et al. [46] (reported also by Tirumani et al. [54] and Lui et al. [55]) the pathogenetic mechanism underlying intestinal infarcts in critical COVID-19 patients might be the thrombotic diathesis due to the inflammatory response to the infection. On CT examination we can see mesenteric arterial or venous filling defects, the "paper sheet wall" sign or the "target" sign with thickened wall, constituted by hyperdense mucosa and hypodense submucosa. In the more advanced stages this condition evolves with findings of hydro-aerial levels, and parietal and portomesenteric pneumatosis (Figure 12). Tirumani et al. [54] observed the frequency of intestinal infarction in 1/72 COVID-19 patients investigated with CT examination (1.3\%). 


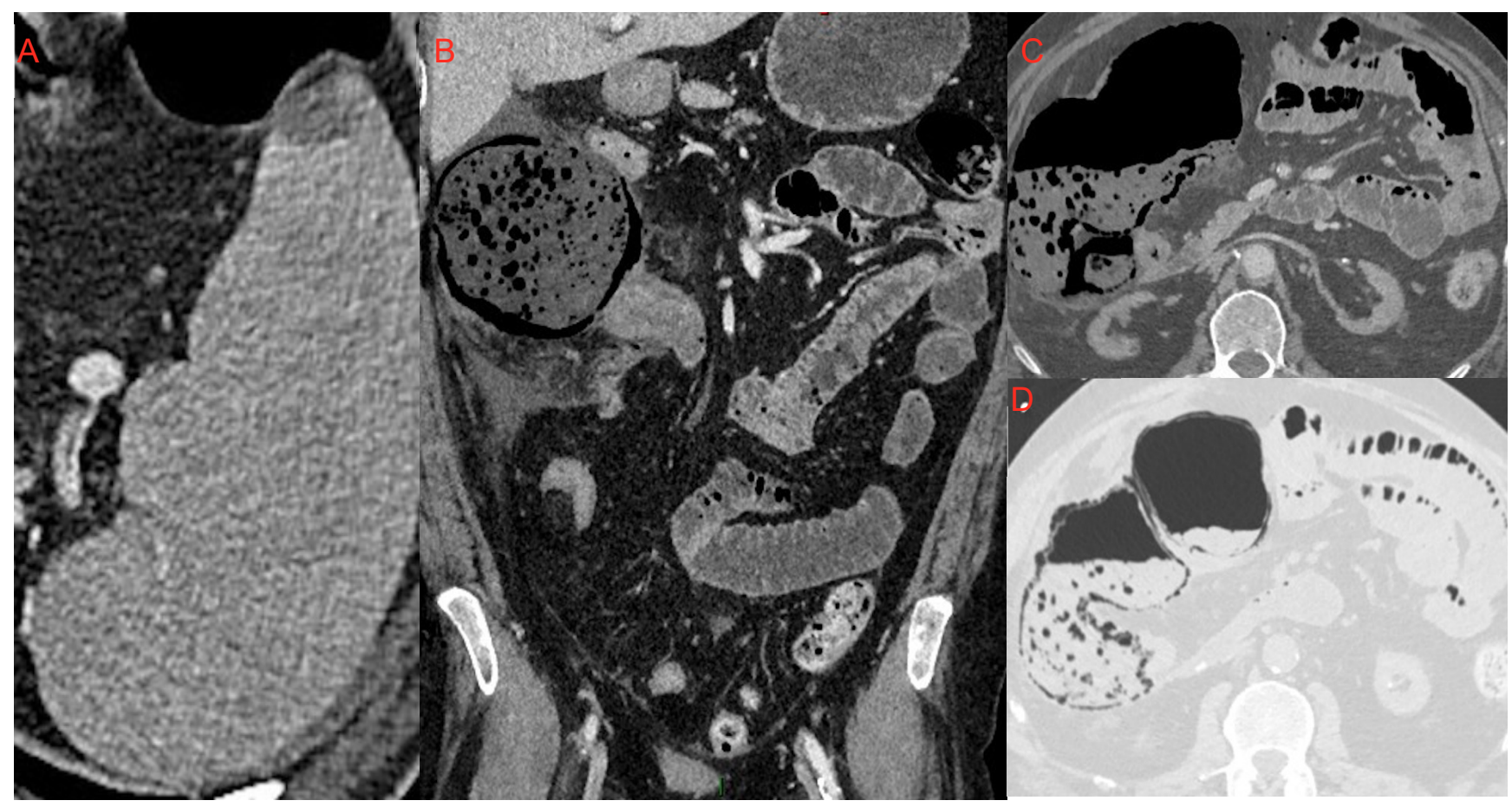

Figure 12. Small area of splenic infarction (A); infarction of the cecum and right colon (B-D): It is possible to notice the marked dilatation of the ascending colon, with parietal pneumatosis and hydro-aerial levels. It was associated with abdominal effusion in right subhepatic space and paracolic gutter which extended to the pelvic cavity.

\subsection{Pancreatitis}

Because of the expression of ACE-2 receptors also in pancreatic cells, pancreatitis can occur in COVID-19 patients [46-48] (Figure 13). Funt et al. [47] investigated the presentation rate of pancreatitis in COVID-19 patients examined with CT, which amounted to $1.5 \%$. They searched for the most common causes of abdominal pain in two groups of patients: COVID-19 positive and COVID-19 negative, respectively. In the subset of acute disease, they documented: inflamed bowel, pancreatitis, pyelonephritis or cystitis more frequently in COVID-19+ patients rather than in COVID-19- patients. As illustrated by Wang et al. [56], pancreatitis presents in COVID-19 with a variable percentage ranging from $1-2 \%$ of mild cases to $17 \%$ of severe cases. Bozdag A. et al. [57] argue that in the literature the pancreatitis diagnosis was based only on amylase and lipase elevation, while the radiological findings were described only in case reports. In one case report necrotizing pancreatitis was described [58].

\subsection{Colitis, Enteritis}

Goldberg-Stein et al. [46] reported that the abnormalities of the gastrointestinal tract were the most common extra-pulmonary CT manifestations in COVID-19 patients. This result was in agreement with those referred by Bhayana et al. [48], who found that $29 \%$ of CT scans showed intestinal wall thickening involving the colon or small intestine. The frequency of wall thickening in the gastrointestinal tract in the study by Goldberg Stein [46] was lower (15\%); they justify this difference by the fact that the intestinal wall thickening may be relatively underestimated in the clinical setting compared to the experimental one (Figure 14).

\subsection{Cystitis and Cholecystitis}

Goldberg-Stein et al. [46] and Funt et al. [47] reported cystitis in 5\% and 4,1\% of COVID-19 cases, respectively, as an edematous thickening of the bladder wall with an hyperdense aspect of the mucosa after contrast medium administration (Figure 15). In 
the Goldberg-Stein et al. [46] paper, CT abnormal findings related to the gallbladder and biliary system were reported in $25 \%$ of cases, including distention of the gallbladder, mural oedema, and findings reported as possible or definite acute cholecystitis (Figure 15); 10\% of patients had bile duct dilatation. In two studies it is explained that there may be an unclear SARS-CoV-2-induced cytopathic effect on hepatocytes, or an ACE-2 receptor-mediated direct viral infection $[59,60]$. Since gallbladder wall oedema is a common finding in acute hepatitis, and is an independent predictor of a more severe clinical course [61], it is possible that gallbladder wall oedema seen in some of the patients is a reflex of hepatocellular damage, either directly induced by SARS-CoV-2, or through an inflammatory response. Further studies are needed to determine the link between COVID-19 positivity and biliary and gallbladder pathologic implication.

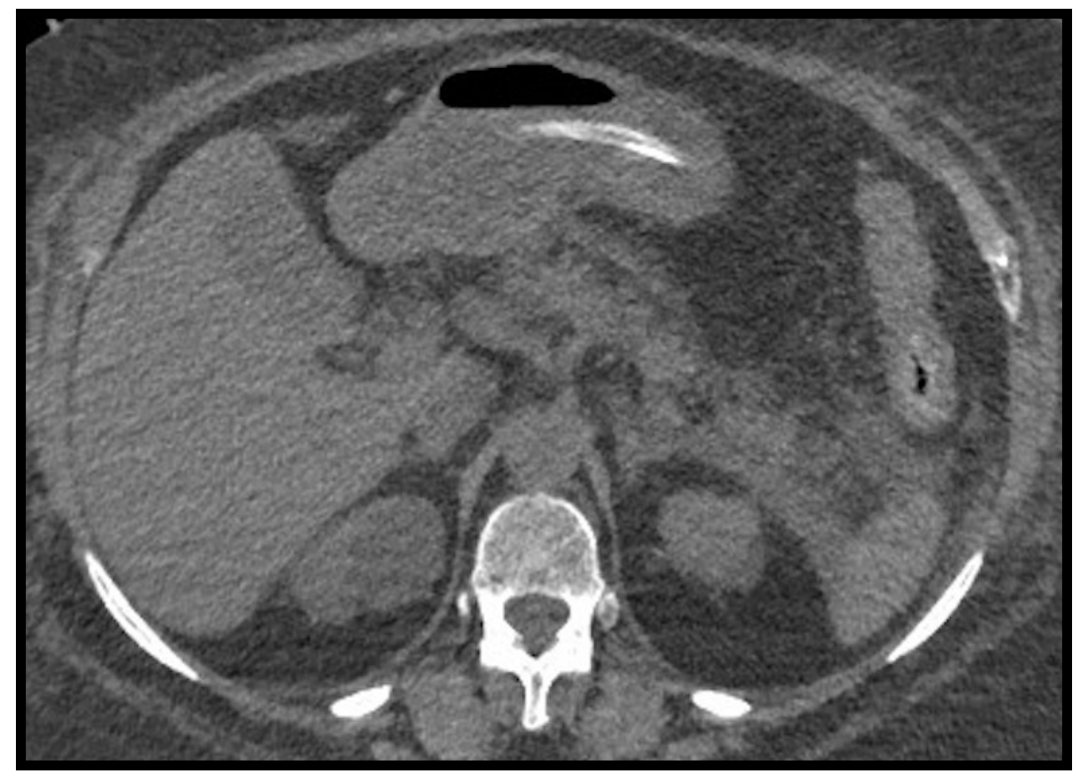

Figure 13. Pancreatitis. Enlarged and edematous pancreas especially at the head, with fat stranding and peripancreatic fluid collection extending along the left anterior pararenal space.

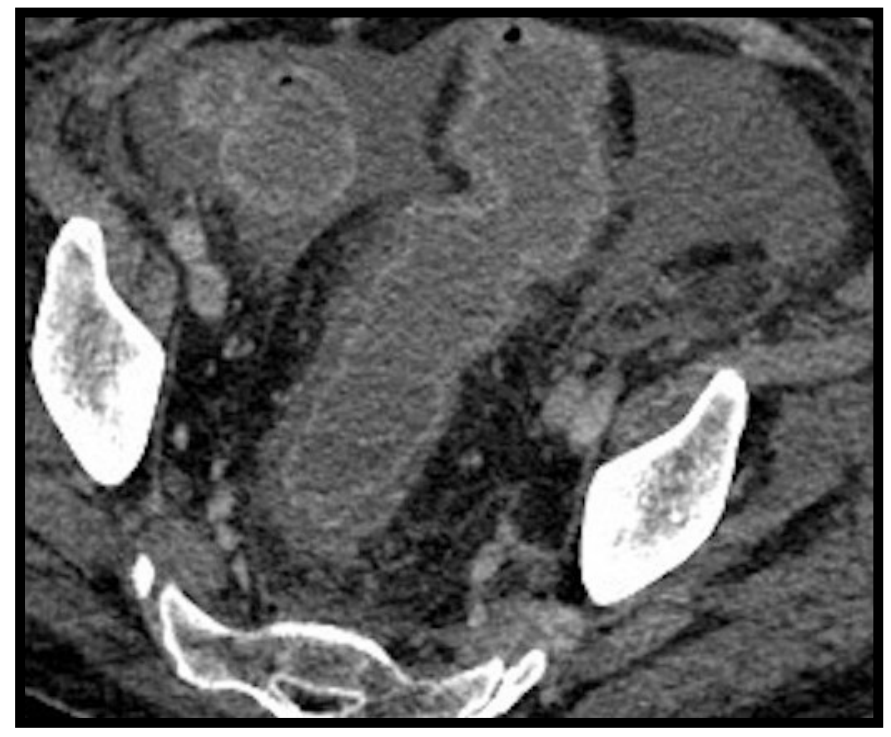

Figure 14. Colitis. Edematous thickening of the walls of the rectum-sigma with hyperdense aspects of the mucosa showing contrast enhancement after administration of contrast medium. Intra-abdominal effusion is associated. 

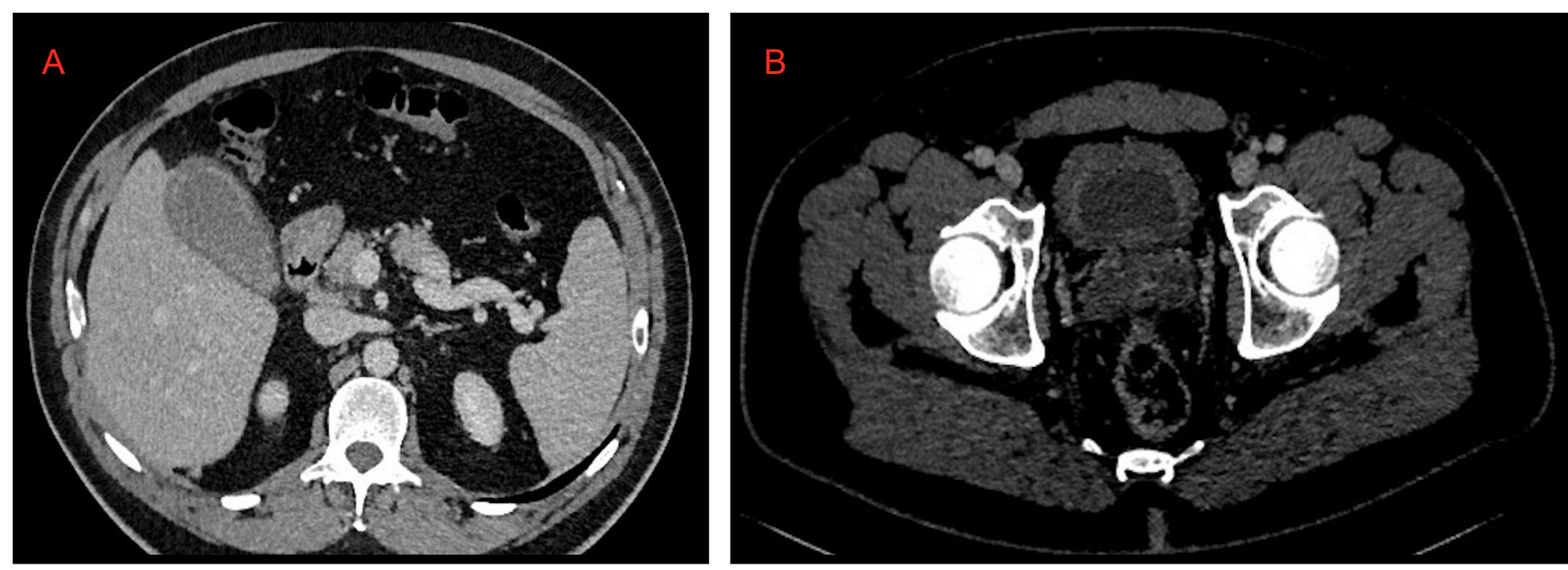

Figure 15. (A) Cholecystitis and (B) cystitis.

Table 3 summarizes all the studies reported in the Section 4: Adult "Abdominal" COVID-19.

Table 3. Adults "Abdominal” COVID-19.

\begin{tabular}{|c|c|c|c|c|c|c|c|}
\hline & $\begin{array}{c}\text { Acute } \\
\text { Aortic } \\
\text { Occlusion } \\
\text { (AAO) }\end{array}$ & $\begin{array}{l}\text { Kidney/Splenic/Intestinal } \\
\text { Infarction }\end{array}$ & Pancreatitis & $\begin{array}{l}\text { Bowel Thickening } \\
\text { (Colitis/Enteritis) }\end{array}$ & Cystitis & $\begin{array}{l}\text { Cholecystitis } \\
\text { and Biliary } \\
\text { System } \\
\text { Manifestation }\end{array}$ & \\
\hline Authors & & & & & & & Total \\
\hline Goldberg Stein et al. [46] & & $5 \% / 5 \% /-$ & & $15 \%$ & $5 \%$ & $25 \%$ & 80 \\
\hline Stacey Funt et al. [47] & & & $1.5 \%$ & $6.8 \%$ & $4.1 \%$ & & 338 \\
\hline Bhayana et al. [48] & & $2.4 \%$ & & $29 \%$ & & & 42 \\
\hline Baeza et al. [53] (case rep) & 3 cases & & & & & & - \\
\hline Sree Tirumani et al [54] & & $1.3 \% /-/ 1.3 \%$ & & $1.3 \%$ & & & 72 \\
\hline
\end{tabular}

\section{Pediatric "Abdominal" COVID-19 Manifestations}

Abdominal manifestations of COVID-19 in children include mainly gastrointestinal (GI), hepatobiliary and pancreatic involvement. Multisystem inflammatory syndrome in children (MIS-C) is a complex entity that usually involves the gastrointestinal tract.

\subsection{Gastrointestinal Manifestations}

As explained above, SARS-CoV-2 enters cells via the angiotensin-converting enzyme-2 (ACE-2) receptor, which is abundantly expressed on lung cells, but also on many extrapulmonary tissues, including gastrointestinal (GI) tract, heart, liver, and kidney [62].

A number of studies have tried to estimate the prevalence of gastroenteric involvement in COVID-19 infection in children, which is matter of debate: Miller et al. [63] showed that gastrointestinal manifestations were present in $84.1 \%$ of children admitted to the hospital and were more often associated with fever and rash; Akobeng et al. [64] in a metaanalysis including 280 children from 9 studies estimated that the pooled prevalence of gastrointestinal manifestations was $22.8 \%$, with diarrhea as the most common presentation $(12.4 \%)$, followed by vomiting (10.3\%) and abdominal pain $(5.4 \%)$.

GI signs and symptoms appear characteristically as presenting features of SARS-CoV2-related multisystem inflammatory syndrome in children (MIS-C), a condition described below [63].

Little is known about typical imaging findings in COVID-19 pediatric patients with GI symptoms. Abdominal ultrasonography, computed tomography or magnetic resonance imaging may be taken into consideration in patients with a severe course of disease or relevant blood test alterations. Miller et al. [63] collected images from 15 patients with 
GI symptoms, finding: mesenteric adenitis, biliary sludge or acalculous cholecystitis, and ascites. In three patients, ultrasonography or magnetic resonance imaging showed bowel wall thickening.

Tullie et al. [65] found on abdominal ultrasound the presence of lymphadenopathy, inflammatory fat throughout the mesentery, and thickening of the terminal ileum, that were confirmed with CT examination when performed.

Less frequent manifestations of GI SARS-CoV-2 involvement are reported in the literature, consisting mainly of acute appendicitis, phlegmonous ileocolitis, intussusception, pneumatosis intestinalis and protein losing enteropathy [66].

\subsection{Hepatobiliary and Pancreatic Involvement}

A study demonstrated that the distribution of ACE-2 is peculiar; it is highly expressed in the endothelial layer of small blood vessels but not in the sinusoidal endothelium [67]. Its concentration on the surface of cholangiocytes is higher than of the hepatocyte surface and is similar to the type II lungs alveolar cells [68]. SARS-CoV-2 may have the ability to infect cholangiocytes via the ACE-2 receptor and directly dysregulate liver function [67]. Moreover, the induced intestinal inflammation impairs the intestinal mucosal barrier, allowing easy access to the circulation and the possibility to reach and affect other organs, including the liver [69].

Hepatitis was defined as an elevation of alanine aminotransferase (ALT) $>40$ and aspartate aminotransferase $(\mathrm{AST})>50$, as these values fall above the $97^{\circ}$ percentile for all ages and both sexes, as defined by Bussler et al. [70].

A mild increase in liver enzymes is well described in COVID-19 pediatric patients, with various results among studies, ranging from $13 \%$ to $50 \%$; however, serious liver dysfunction is uncommon [71]. Elevated aspartate aminotransferase levels (>50 UI/L) are observed more frequently than alanine aminotransferase levels ( $>45 \mathrm{UI} / \mathrm{L})$ [72].

Cantor et al. [73] described abdominal imaging performed on patients with hepatitis. Abdominal ultrasounds showed abnormal liver-associated manifestation such as: significant ascites, hepatomegaly or a thick-walled gallbladder. One of the two magnetic resonance imaging studies showed ascites.

SARS-CoV-2 can affect both the exocrine and endocrine pancreas; an abnormal elevation of amylase and lipase, together with glucose dysregulation and acute diabetes, are described in pediatric patients with severe COVID-19 pneumonia, with development of acute pancreatitis [74].

A few cases of pancreatic involvement have been reported in the literature in pediatric patients. Samies et al. [75] illustrated three cases of pancreatitis in children affected by COVID-19 that were diagnosed by laboratory tests and imaging (ultrasound or CT examinations).

Both hepatitis and pancreatitis are observed more frequently in association with MIS-C, as displayed below.

Table 4 summarizes all the studies reported in Section 5: Pediatric "Abdominal" COVID-19 Manifestations.

Table 4. Pediatric "Abdominal" COVID-19 Manifestation.

\begin{tabular}{|c|c|c|c|c|}
\hline & GI Involvement & $\begin{array}{l}\text { Hepato-Biliary } \\
\text { Involvement }\end{array}$ & $\begin{array}{c}\text { Pancreatic } \\
\text { Involvement }\end{array}$ & \\
\hline Authors & & & & Total \\
\hline Miller et al. [63] & $20 \%$ & & & 15 \\
\hline $\begin{array}{l}\text { Tullie et al. [65] } \\
\text { (case rep) }\end{array}$ & 5 cases & & & - \\
\hline Cantor et al. [73] & & $11 \%$ & & 44 \\
\hline $\begin{array}{l}\text { Samie et al. [75] } \\
\text { (case rep) }\end{array}$ & & & 3 cases & - \\
\hline
\end{tabular}




\subsection{MIS-C}

The multisystem inflammatory syndrome in children (MIS-C), already mentioned above [35-38], reported in patients under 19 years old who have a history of exposure to SARS-CoV-2, has features that extensively involve the abdomen.

In regard to abdominal MIS-C, Caro-Dominguez et al. [38] found that the most common abnormalities in US, CT and MRI were free fluid (71\%) and terminal ileum wall thickening (57\%) (Figure 16); other less common findings were hepatomegaly, right iliac fossa lymphadenopathy, gallbladder wall oedema, gallbladder sludge, periportal oedema, splenomegaly and haemorrhagic cystitis. According to Palabiyik et al. [40] the most conventional US and CT findings were hepatomegaly and hepatosplenomegaly, followed by periportal and pericholecystic wall oedema, mesenteric lymph nodes in the right lower quadrant, free fluid in the abdomen, temporary invagination, echogenic kidneys and a case of pancreatic alterations. Additionally, in the series of Hameed et al. [43], the most common US and CT abdominal findings were represented by anechoic free fluid (53\%), localized inflammatory change within the right iliac fossa ( $47 \%)$, a combination of echogenic expanded mesenteric fat (37\%), and multiple mildly enlarged lymph nodes in $47 \%$ of cases.

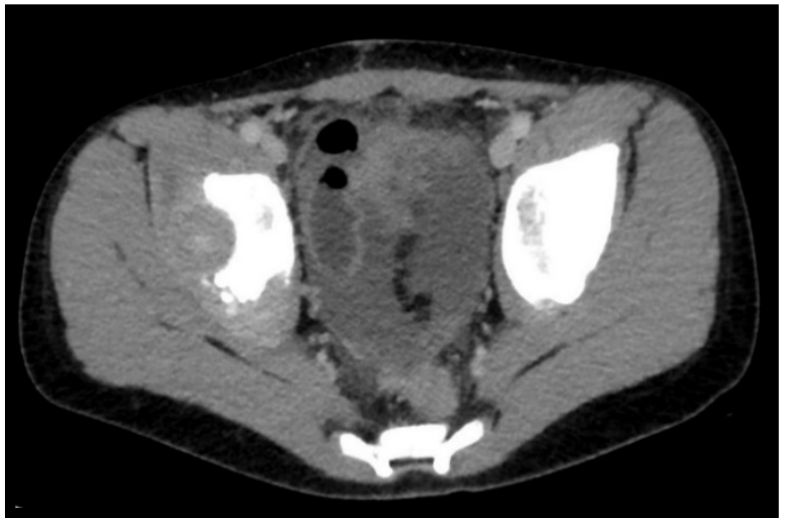

(A)

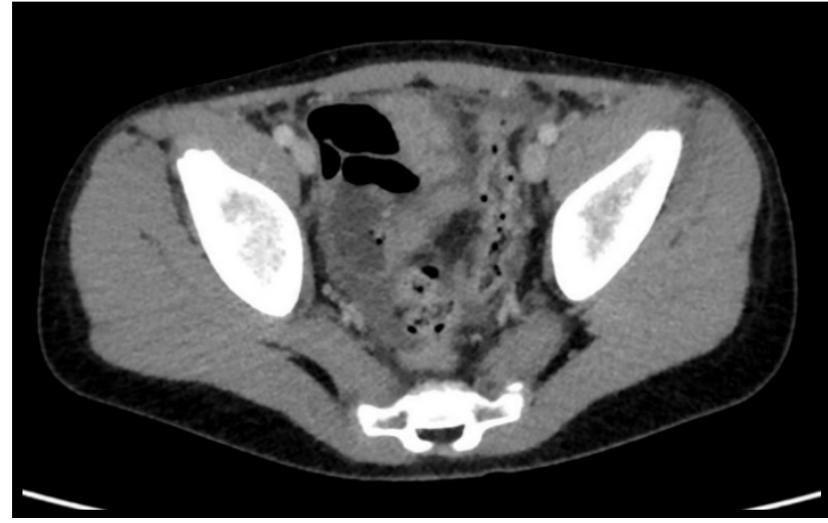

(B)

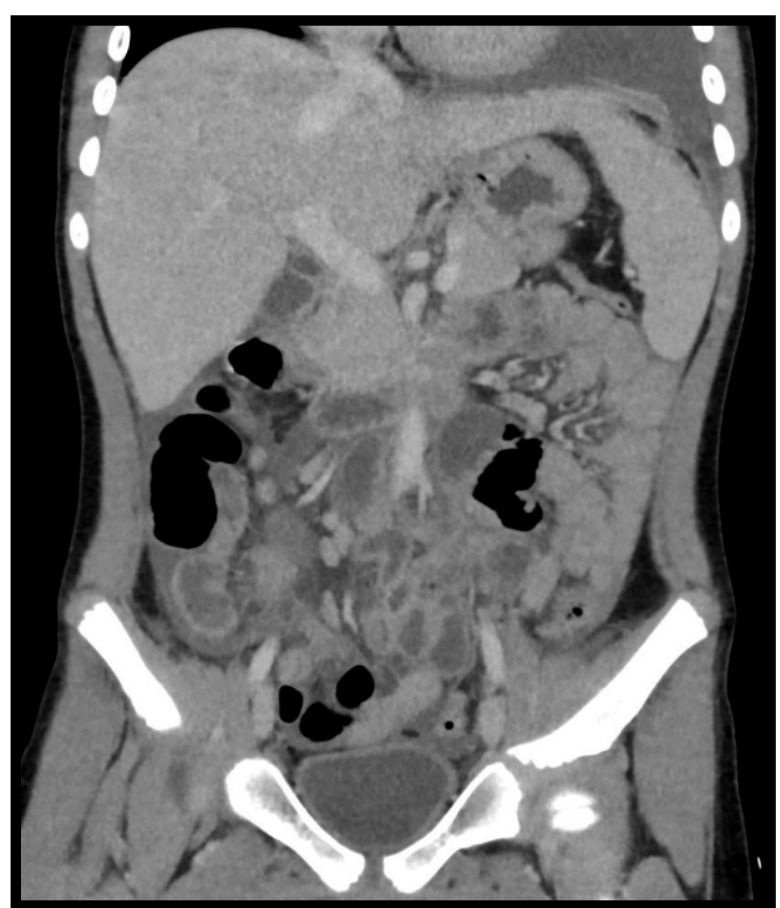

(C)

Figure 16. An 11-year-old patient with MIS-C. (A-C): Abdominal effusion with cecum and sigma hyper enhancing wall thickening. 


\section{Conclusions}

In conclusion, this pictorial review shows the multiple aspects of COVID-19 infection which make it a multi-organ disease. These aspects must be known and investigated to obtain the best stratification and ensure optimal treatment for the patient. In fact, although lymphadenopathies, pleural and pericardial effusion, bronchiectases, halo sign, reverse halo sign and cavitations are notoriously associated with bacterial and fungal pneumonia, our review aims to underline (through the scientific data reported), that these manifestations are found in a non-negligible percentage of COVID-19 cases. Furthermore, these atypical thoracic and gastrointestinal manifestations are associated with more severe clinical settings, with systemic involvement and poor prognosis. We believe that these findings can give a real clinical contribution by helping the clinicians to recognize COVID19 "red flags" associated with worse scenarios. CT is the best imaging method in this environment, because it can be used to assess the progression of the disease and the multisystem involvement.

Author Contributions: Conceptualization, A.S. (Arnaldo Scardapane) and C.M.; methodology, A.S. (Arnaldo Scardapane); software M.D.C.; validation A.G., A.A.S.I. and A.S. (Antonello Sacco); formal analysis, P.P.; investigation M.F. and F.L.; resources A.A.S.I.; data curation M.F.; writing-original draft preparation C.M. and A.S. (Arnaldo Scardapane); writing-review and editing C.M. and F.L.; visualization, M.F., M.C. and G.S.; supervision, A.S. (Arnaldo Scardapane); All authors have read and agreed to the published version of the manuscript..

Funding: This research received no external funding.

Institutional Review Board Statement: Not applicable.

Informed Consent Statement: Informed consent was obtained from all subjects involved in cases reported in this review.

Data Availability Statement: The authors confirm that the data supporting the findings of this review are available within the article and its references list.

Conflicts of Interest: The authors declare no conflict of interest.

\section{References}

1. Epicentro: L'epidemiologia per la Sanità Pubblica; Istituto Superiore di Sanità (ISS). ISS Website. Available online: https: //www.epicentro.iss.it/coronavirus/sars-cov-2 (accessed on 20 July 2021).

2. Scardapane, A.; Villani, L.; Bavaro, D.F.; Passerini, F.; Ianora, A.A.S.; Lucarelli, N.M.; Angarano, G.; Portincasa, P.; Palmieri, V.O.; Saracino, A. Pulmonary artery filling defects in COVID-19 patients revealed using CT pulmonary angiography: A predictable complication? BioMed Res. Int. 2021, 2021, 8851736. [CrossRef]

3. Zhu, J.; Zhong, Z.; Li, H.; Ji, P.; Pang, J.; Li, B.; Zhang, J. CT imaging features of 4121 patients with COVID-19: A meta-analysis. J. Med. Virol. 2020, 92, 891-902. [CrossRef]

4. Simpson, S.; Kay, F.U.; Abbara, S.; Bhalla, S.; Chung, J.H.; Chung, M.; Henry, T.S.; Kanne, J.P.; Kligerman, S.; Ko, J.P.; et al. Radiological society of North America expert consensus document on reporting chest CT findings related to COVID-19: Endorsed by the Society of Thoracic Radiology, the American College of Radiology, and RSNA. Radiol. Cardiothorac. Imaging 2020, 2 , e200152. [CrossRef] [PubMed]

5. Caruso, D.; Polidori, T.; Guido, G.; Nicolai, M.; Bracci, B.; Cremona, A.; Zerunian, M.; Polici, M.; Pucciarelli, F.; Rucci, C.; et al. Typical and atypical COVID-19 computed tomography findings. World J. Clin. Cases 2020, 8, 3177-3187. [CrossRef]

6. Gurumurthy, B.; Das, S.K.; Hiremath, R.; Shetty, S.; Hiremath, A.; Gowda, T. Spectrum of atypical pulmonary manifestations of COVID-19 on computed tomography. Egypt. J. Radiol. Nucl. Med. 2021, 52, 1-13. [CrossRef]

7. Parra Gordo, M.L.; Weiland, G.B.; García, M.G.; Choperena, G.A. Radiologic aspects of COVID-19 pneumonia: Outcomes and thoracic complications. Radiologia 2021, 63, 74-88. [CrossRef]

8. Li, K.; Wu, J.; Wu, F.; Guo, D.; Chen, L.; Fang, Z.; Li, C. The Clinical and Chest CT Features Associated With Severe and Critical COVID-19 Pneumonia. Investig. Radiol. 2020, 55, 327-331. [CrossRef]

9. Grassi, R.; Fusco, R.; Belfiore, M.P.; Montanelli, A.; Patelli, G.; Urraro, F.; Petrillo, A.; Granata, V.; Sacco, P.; Mazzei, M.A.; et al. Coronavirus disease 2019 (COVID-19) in Italy: Features on chest computed tomography using a structured report system. Sci. Rep. 2020, 10, 17236. [CrossRef]

10. Li, X.; Fang, X.; Bian, Y.; Lu, J. Comparison of chest CT findings between COVID-19 pneumonia and other types of viral pneumonia: A two-center retrospective study. Eur. Radiol. 2020, 30, 5470-5478. [CrossRef] 
11. Zhou, S.; Wang, Y.; Zhu, T.; Xia, L. CT Features of Coronavirus Disease 2019 (COVID-19) Pneumonia in 62 Patients in Wuhan, China. Am. J. Roentgenol. 2020, 214, 1287-1294. [CrossRef] [PubMed]

12. Darwish, H.S.; Habash, M.Y.; Habash, W.Y. Chest computed tomography imaging features in patients with coronavirus disease 2019 (COVID-19). J. Int. Med. Res. 2021, 49, 1-8. [CrossRef]

13. Sabri, A.; Davarpanah, A.H.; Mahdavi, A.; Abrishami, A.; Khazaei, M.; Heydari, S.; Asgari, R.; Nekooghadam, S.M.; Dobranowski, J.; Taheri, M.S. Novel coronavirus disease 2019: Predicting prognosis with a computed tomography-based disease severity score and clinical laboratory data. Pol. Arch. Intern. Med. 2020, 130, 629-634. [CrossRef]

14. Shi, S.; Qin, M.; Shen, B.; Cai, Y.; Liu, T.; Yang, F.; Gong, W.; Liu, X.; Liang, J.; Zhao, Q.; et al. Association of cardiac injury with mortality in hospitalized patients with COVID-19 in Wuhan, China. JAMA Cardiol. 2020, 5, 802-810. [CrossRef]

15. Salehi, S.; Abedi, A.; Balakrishnan, S.; Gholamrezanezhad, A. Coronavirus disease 2019 (COVID-19): A systematic review of imaging findings in 919 patients. Am. J. Roentgenol. 2020, 215, 87-93. [CrossRef] [PubMed]

16. Auger, R.; Dujardin, P.-A.; Bleuzen, A.; Buraschi, J.; Mandine, N.; Marchand-Adam, S.; Pearson, A.; Derot, G. Chest computed tomography signs associated with pejorative evolution in COVID-19 patients. Pol. J. Radiol. 2021, 86, 115-121. [CrossRef]

17. Devie, A.; Kanagaratnam, L.; Perotin, J.-M.; Jolly, D.; Ravey, J.-N.; Djelouah, M.; Hoeffel, C. COVID-19: A qualitative chest CT model to identify severe form of the disease. Diagn. Interv. Imaging 2020, 102, 77-84. [CrossRef]

18. Wu, J.; Pan, J.; Teng, D.; Xu, X.; Feng, J.; Chen, Y.-C. Interpretation of CT signs of 2019 novel Coronavirus (COVID-19) pneumonia. Eur. Radiol. 2020, 30, 1-8. [CrossRef]

19. Bernheim, A.; Mei, X.; Huang, M.; Yang, Y.; Fayad, Z.A.; Zhang, N.; Diao, K.; Lin, B.; Zhu, X.; Li, K.; et al. Chest CT Findings in Coronavirus Disease-19 (COVID-19): Relationship to Duration of Infection. Radiology 2020, 295, 200463. [CrossRef] [PubMed]

20. Kuang, P.-D.; Wang, C.; Zheng, H.-P.; Ji, W.-B.; Gao, Y.-T.; Cheng, J.-M.; Ma, J.-B.; Liu, Y.-Q.; Su, M.-G.; Ruan, G.-X.; et al. Comparison of the clinical and CT features between COVID-19 and H1N1 influenza pneumonia patients in Zhejiang, China. Eur. Rev. Med. Pharm. Sci. 2021, 25, 1135-1145.

21. Koo, H.J.; Lim, S.; Choe, J.; Choi, S.-H.; Sung, H.; Do, K.-H. Radiographic and CT features of viral pneumonia. RadioGraphics 2018, 38, 719-739. [CrossRef] [PubMed]

22. Wong, K.T.; Antonio, G.E.; Hui, D.; Lee, N.; Yuen, E.H.Y.; Wu, A.; Leung, C.B.; Rainer, T.; Cameron, P.; Chung, S.S.C.; et al. Severe Acute Respiratory syndrome: Radiographic appearances and pattern of progression in 138 patients. Radiology 2003, 228, 401-406. [CrossRef] [PubMed]

23. Ajlan, A.M.; Ahyad, R.A.; Jamjoom, L.G.; Alharthy, A.; Madani, T.A. Middle East respiratory syndrome coronavirus (MERS-CoV) infection: Chest CT findings. AJR Am. J. Roentgenol. 2014, 203, 782-787. [CrossRef] [PubMed]

24. Zoumot, Z.; Bonilla, M.-F.; Wahla, A.S.; Shafiq, I.; Uzbeck, M.; El-Lababidi, R.M.; Hamed, F.; Abuzakouk, M.; ElKaissi, M. Pulmonary cavitation: An under-recognized late complication of severe COVID-19 lung disease. BMC Pulm. Med. 2021, 21, 24. [CrossRef]

25. Vega, J.M.L.; Gordo, M.L.P.; Tascón, A.D.; Vélez, S.O. Pneumomediastinum and spontaneous pneumothorax as an extrapulmonary complication of COVID-19 disease. Emerg. Radiol. 2020, 27, 727-730. [CrossRef] [PubMed]

26. Loffi, M.; Regazzoni, V.; Sergio, P.; Martinelli, E.; Stifani, I.; Quinzani, F.; Robba, D.; Cotugno, A.; DeDe, M.; Danzi, G.B. Spontaneous pneumomediastinum in COVID-19 pneumonia. Monaldi Arch. Chest Dis. 2020, 90, 604-607. [CrossRef] [PubMed]

27. Caro-Dominguez, P.; Shelmerdine, S.C.; Toso, S.; Secinaro, A.; Toma, P.; Damasio, M.B.; Navallas, M.; Riaza-Martin, L.; GomezPastrana, D.; Mahani, M.G.; et al. Thoracic imaging of coronavirus disease 2019 (COVID-19) in children: A series of 91 cases. Pediatr. Radiol. 2020, 50, 1354-1368. [CrossRef] [PubMed]

28. Duan, Y.-N.; Zhu, Y.-Q.; Tang, L.-L.; Qin, J. CT features of novel coronavirus pneumonia (COVID-19) in children. Eur. Radiol. 2020, 30, 4427-4433. [CrossRef] [PubMed]

29. Zhang, Y.; Xie, R.-M.; He, Y.-L.; Xing, L.-H.; Dong, L.; Zhang, J.-Z.; Xing, W.-H.; Lv, X.-Y.; Lu, Y.-B.; Liu, Q.; et al. Clinical and imaging features of pediatric COVID-19. Ital. J. Pediatr. 2020, 46, 1-9. [CrossRef] [PubMed]

30. Ugas-Charcape, C.F.; Ucar, M.E.; Almanza-Aranda, J.; Rizo-Patrón, E.; Lazarte-Rantes, C.; Caro-Domínguez, P.; Cadavid, L.; Pérez-Marrero, L.; Fazecas, T.; Gomez, L.; et al. Pulmonary imaging in coronavirus disease 2019 (COVID-19): A series of 140 Latin American children. Pediatr. Radiol. 2021, 1-11. [CrossRef]

31. Foust, A.M.; Phillips, G.S.; Chu, W.C.; Daltro, P.; Das, K.M.; Garcia-Peña, P.; Kilborn, T.; Winant, A.J.; Lee, E.Y. International Expert Consensus Statement on Chest Imaging in Pediatric COVID-19 Patient Management: Imaging Findings, Imaging Study Reporting, and Imaging Study Recommendations. Radiol. Cardiothorac. Imaging 2020, 2, e200214. [CrossRef]

32. Xia, W.; Shao, J.; Guo, Y.; Peng, X.; Li, Z.; Hu, D. Clinical and CT features in pediatric patients with COVID-19 infection: Different points from adults. Pediatr. Pulmonol. 2020, 55, 1169-1174. [CrossRef] [PubMed]

33. Buonsenso, D.; Gatto, A.; Graglia, B.; Rivetti, S.; Ferretti, S.; Paradiso, F.V.; Chiaretti, A. Early spontaneous pneumothorax, pneumomediastinum and pneumorrhachis in an adolescent with SARS-CoV-2 infection. Eur. Rev. Med. Pharmacol. Sci. 2021, 25, 4413-4417. [CrossRef]

34. Montgomery, A.; Finck, C. Spontaneous hemopneumothorax in an adolescent with COVID-19. J. Pediatr. Surg. Case Rep. 2021, 69, 101852. [CrossRef]

35. World Health Organization. Multisystem Inflammatory Syndrome in Children and Adolescents with COVID-19. Scientific Brief. WHO Website. Available online: https://www.who.int/publications/i/item/multisystem-inflammatory-syndrome-in-childrenand-adolescents-with-covid-19 (accessed on 20 July 2021). 
36. Centers for Disease Control and Prevention. Multisystem Inflammatory Syndrome in Children (MIS-C) Associated with Coronavirus Disease 2019 (COVID-19). CDC Website. Available online: https:/ / emergency.cdc.gov/han/2020/han00432.asp (accessed on 20 July 2021).

37. Whittaker, E.; Bamford, A.; Kenny, J.; Kaforou, M.; Jones, C.; Shah, P.; Ramnarayan, P.; Fraisse, A.; Miller, O.; Davies, P.; et al. Clinical Characteristics of 58 Children With a Pediatric Inflammatory Multisystem Syndrome Temporally Associated with SARS-CoV-2. JAMA 2020, 324, 259-269. [CrossRef] [PubMed]

38. Caro-Domínguez, P.; Navallas, M.; Riaza-Martin, L.; Mahani, M.G.; Charcape, C.F.U.; Valverde, I.; D'Arco, F.; Toso, S.; Shelmerdine, S.C.; van Schuppen, J.; et al. Imaging findings of multisystem inflammatory syndrome in children associated with COVID-19. Pediatr. Radiol. 2021, 1-13. [CrossRef]

39. Winant, A.J.; Blumfield, E.; Liszewski, M.C.; Kurian, J.; Foust, A.M.; Lee, E.Y. Thoracic Imaging Findings of Multisystem Inflammatory Syndrome in Children Associated with COVID-19: What Radiologists Need to Know Now. Radiol. Cardiothorac. Imaging 2020, 2, e200346. [CrossRef]

40. Palabiyik, F.; Akcay, N.; Sevketoglu, E.; Hatipoglu, N.; Sari, E.E.; Inci, E. Imaging of Multisystem Inflammatory Disease in Children (MIS-C) Associated With COVID-19. Acad. Radiol. 2021, 28, 1200-1208. [CrossRef]

41. Blumfield, E.; Levin, T.L.; Kurian, J.; Lee, E.Y.; Liszewski, M.C. Imaging Findings in Multisystem Inflammatory Syndrome in Children (MIS-C) Associated With Coronavirus Disease (COVID-19). AJR Am. J. Roentgenol. 2021, 216, 507-517. [CrossRef]

42. Sánchez-Oro, R.; Bandpey, M.F.; Martínez, E.G.; Prades, M.E.; Muñoz, E.A. Clinical and radiological findings for the new multisystem inflammatory syndrome in children associated with COVID-19. Radiologia 2021, 63, 334-344. [CrossRef]

43. Hameed, S.; Elbaaly, H.; Reid, C.E.L.; Santos, R.M.F.; Shivamurthy, V.; Wong, J.; Jogeesvaran, K.H. Spectrum of Imaging Findings at Chest Radiography, US, CT, and MRI in Multisystem Inflammatory Syndrome in Children Associated with COVID-19. Radiology 2021, 298, E1-E10. [CrossRef]

44. Rostad, B.S.; Shah, J.H.; Rostad, C.A.; Jaggi, P.; Richer, E.J.; Linam, L.E.; Alazraki, A.L.; Riedesel, E.L.; Milla, S.S. Chest radiograph features of multisystem inflammatory syndrome in children (MIS-C) compared to pediatric COVID-19. Pediatr. Radiol. 2021, 51, 231-238. [CrossRef]

45. Verdoni, L.; Mazza, A.; Gervasoni, A.; Martelli, L.; Ruggeri, M.; Ciuffreda, M.; Bonanomi, E.; D'Antiga, L. An outbreak of severe Kawasaki-like disease at the Italian epicentre of the SARS-CoV-2 epidemic: An observational cohort study. Lancet 2020, 395, 1771-1778. [CrossRef]

46. Goldberg-Stein, S.; Fink, A.; Paroder, V.; Kobi, M.; Yee, J.; Chernyak, V. Abdominopelvic CT findings in patients with novel coronavirus disease 2019 (COVID-19). Abdom. Radiol. 2020, 45, 2613-2623. [CrossRef] [PubMed]

47. Funt, S.A.; Cohen, S.L.; Wang, J.J.; Sanelli, P.C.; Barish, M.A. Abdominal pelvic CT findings compared between COVID-19 positive and COVID-19 negative patients in the emergency department setting. Abdom. Radiol. 2021, 46, 1498-1505. [CrossRef] [PubMed]

48. Bhayana, R.; Som, A.; Li, M.D.; Carey, D.E.; Anderson, M.A.; Blake, M.A.; Catalano, O.; Gee, M.S.; Hahn, P.F.; Harisinghani, M.; et al. Abdominal Imaging Findings in COVID-19: Preliminary Observations. Radiology 2020, 297, E207-E215. [CrossRef]

49. Tang, N.; Li, D.; Wang, X.; Sun, Z. Abnormal coagulation parameters are associated with poor prognosis in patients with novel coronavirus pneumonia. J. Thromb. Haemost. 2020, 18, 844-847. [CrossRef]

50. Caruso, D.; Zerunian, M.; Polici, M.; Pucciarelli, F.; Polidori, T.; Rucci, C.; Guido, G.; Bracci, B.; De Dominicis, C.; Laghi, A. Chest CT Features of COVID-19 in Rome, Italy. Radiology 2020, 296, E79-E85. [CrossRef] [PubMed]

51. Magro, C.; Mulvey, J.J.; Berlin, D.; Nuovo, G.; Salvatore, S.; Harp, J.; Baxter-Stoltzfus, A.; Laurence, J. Complement associated microvascular injury and thrombosis in the pathogenesis of severe COVID-19 infection: A report of five cases. Transl. Res. 2020, 220, 1-13. [CrossRef] [PubMed]

52. Zhang, Y.; Cao, W.; Xiao, M.; Li, Y.J.; Yang, Y.; Zhao, J.; Zhou, X.; Jiang, W.; Zhao, Y.Q.; Zhang, S.Y.; et al. Clinical and coagulation characteristics of 7 patients with critical COVID-2019 Pneumonia and Acro-Ischemia. Zhonghua Xue Ye Xue Za Zhi 2020, 41 , E006.

53. Baeza, C.; González, A.; Torres, P.; Pizzamiglio, M.; Arribas, A.; Aparicio, C. Acute aortic thrombosis in COVID-19. J. Vasc. Surg. Cases Innov. Tech. 2020, 6, 483-486. [CrossRef]

54. Tirumani, S.H.; Rahnemai-Azar, A.A.; Pierce, J.D.; Parikh, K.D.; Martin, S.S.; Gilkeson, R.; Ramaiya, N.H. Are asymptomatic gastrointestinal findings on imaging more common in COVID-19 infection? Study to determine frequency of abdominal findings of COVID-19 infection in patients with and without abdominal symptoms and in patients with chest-only CT scans. Abdom. Radiol. 2021, 46, 2407-2414. [CrossRef]

55. Lui, K.; Wilson, M.P.; Low, G. Abdominal imaging findings in patients with SARS-CoV-2 infection: A scoping review. Abdom. Radiol. 2020, 46, 1249-1255. [CrossRef]

56. Wang, F.; Wang, H.; Fan, J.; Zhang, Y.; Wang, H.; Zhao, Q. Pancreatic Injury Patterns in Patients With Coronavirus Disease 19 Pneumonia. Gastroenterology 2020, 159, 367-370. [CrossRef] [PubMed]

57. Bozdag, A.; Eroglu, Y.; Tartar, A.S.; Bozdag, P.G.; Aglamis, S. Pancreatic Damage and Radiological Changes in Patients With COVID-19. Cureus 2021, 13. [CrossRef]

58. Kumaran, N.K.; Karmakar, B.K.; Taylor, O.M. Coronavirus disease-19 (COVID-19) associated with acute necrotising pancreatitis (ANP). BMJ Case Rep. 2020, 13, e237903. [CrossRef]

59. Sultan, S.; Altayar, O.; Siddique, S.M.; Davitkov, P.; Feuerstein, J.D.; Lim, J.K.; Falck-Ytter, Y.; El-Serag, H.B. AGA Institute Rapid Review of the Gastrointestinal and Liver Manifestations of COVID-19, Meta-Analysis of International Data, and Recommendations for the Consultative Management of Patients with COVID-19. Gastroenterology 2020, 159, 320-334.e27. [CrossRef] [PubMed] 
60. Fan, Z.; Chen, L.; Li, J.; Cheng, X.; Yang, J.; Tian, C.; Zhang, Y.; Huang, S.; Liu, Z.; Cheng, J. Clinical Features of COVID-19-Related Liver Functional Abnormality. Clin. Gastroenterol. Hepatol. 2020, 18, 1561-1566. [CrossRef]

61. Park, S.J.; Kim, J.D.; Seo, Y.S.; Park, B.J.; Kim, M.J.; Um, S.H.; Kim, C.H.; Yim, H.J.; Baik, S.K.; Jung, J.Y.; et al. Computed tomography findings for predicting severe acute hepatitis with prolonged cholestasis. World J. Gastroenterol. 2013, 19, $2543-2549$. [CrossRef]

62. Hamming, I.; Timens, W.; Bulthuis, M.; Lely, A.; Navis, G.; van Goor, H. Tissue distribution of ACE2 protein, the functional receptor for SARS coronavirus. A first step in understanding SARS pathogenesis. J. Pathol. 2004, 203, 631-637. [CrossRef]

63. Miller, J.; Cantor, A.; Zachariah, P.; Ahn, D.; Martinez, M.; Margolis, K.G. Gastrointestinal Symptoms as a Major Presentation Component of a Novel Multisystem Inflammatory Syndrome in Children That Is Related to Coronavirus Disease 2019: A Single Center Experience of 44 Cases. Gastroenterology 2020, 159, 1571-1574.e2. [CrossRef]

64. Akobeng, A.K.; Grafton-Clarke, C.; Abdelgadir, I.; Twum-Barimah, E.; Gordon, M. Gastrointestinal manifestations of COVID-19 in children: A systematic review and meta-analysis. Frontline Gastroenterol. 2020, 12, 332-337. [CrossRef] [PubMed]

65. Tullie, L.; Ford, K.; Bisharat, M.; Watson, T.; Thakkar, H.; Mullassery, D.; Giuliani, S.; Blackburn, S.; Cross, K.; De Coppi, P.; et al. Gastrointestinal features in children with COVID-19: An observation of varied presentation in eight children. Lancet Child Adolesc. Health 2020, 4, 378-387. [CrossRef]

66. Puoti, M.G.; Rybak, A.; Kiparissi, F.; Gaynor, E.; Borrelli, O. SARS-CoV-2 and the Gastrointestinal Tract in Children. Front. Pediatr 2021, 9, 67. [CrossRef]

67. Jothimani, D.; Venugopal, R.; Abedin, M.F.; Kaliamoorthy, I.; Rela, M. COVID-19 and the liver. J. Hepatol. 2020, 73, 1231-1240. [CrossRef]

68. Chai, X.; Hu, L.; Zhang, Y.; Han, W.; Lu, Z.; Ke, A. Specific ACE2 expression in cholangiocytes may cause liver damage after 2019-nCoV infection. Bio-Rxiv 2020, 1, 1-13. [CrossRef]

69. Tripathi, A.; Debelius, J.; Brenner, D.A.; Karin, M.; Loomba, R.; Schnabl, B.; Knight, R. The gut-liver axis and the intersection with the microbiome. Nat. Rev. Gastroenterol. Hepatol. 2018, 15, 397-411. [CrossRef]

70. Bussler, S.; Vogel, M.; Pietzner, D.; Harms, K.; Buzek, T.; Penke, M.; Händel, N.; Körner, A.; Baumann, U.; Kiess, W.; et al. New pediatric percentiles of liver enzyme serum levels (alanine aminotransferase, aspartate aminotransferase, $\gamma$-glutamyltransferase): Effects of age, sex, body mass index, and pubertal stage. Hepatology 2018, 68, 1319-1330. [CrossRef]

71. Chiappini, E.; Licari, A.; Motisi, M.A.; Manti, S.; Marseglia, G.L.; Galli, L.; Lionetti, P. Gastrointestinal involvement in children with SARS-COV-2 infection: An overview for the pediatrician. Pediatr. Allergy Immunol. 2020, 31, 92-95. [CrossRef] [PubMed]

72. Parri, N.; Lenge, M.; Buonsenso, D. Children with Covid-19 in pediatric emergency departments in Italy. N. Engl. J. Med. 2020, 383, 187-190. [CrossRef] [PubMed]

73. Cantor, A.; Miller, J.; Zachariah, P.; DaSilva, B.; Margolis, K.; Martinez, M. Acute Hepatitis Is a Prominent Presentation of the Multisystem Inflammatory Syndrome in Children: A Single-Center Report. Hepatology 2020, 72, 1522-1527. [CrossRef] [PubMed]

74. Zippi, M.; Hong, W.; Traversa, G.; Maccioni, F.; De Biase, D.; Gallo, C.; Fiorino, S. Involvement of the exocrine pancreas during COVID-19 infection and possible pathogenetic hypothesis: A concise review. Infez Med. 2020, 28, 507-515. [PubMed]

75. Samies, N.L.; Yarbrough, A.; Boppana, S. Pancreatitis in Pediatric Patients With COVID-19. J. Pediatr. Infect. Dis. Soc. 2021, 10, 57-59. [CrossRef] [PubMed] 